\title{
Biomarkers in respiratory tract infections: diagnostic guides to antibiotic prescription, prognostic markers and mediators
}

\author{
M. Christ-Crain and B. Müller
}

ABSTRACT: Used appropriately, biomarkers improve the assessment of respiratory tract infections and sepsis. Most prominently, circulating procalcitonin levels increase by a factor of several tens of thousands during sepsis. Using a sensitive assay, procalcitonin safely and markedly reduces antibiotic usage in respiratory tract infections and nonbacterial meningitis. Procalcitonin is the protopye of hormokine mediators. The term "hormokine" encompasses the cytokine-like behaviour of hormones during inflammation and infections. The concept is based on a ubiquitous expression of calcitonin peptides during sepsis. Adrenomedullin, another member of the calcitonin peptide superfamily, was shown to complement and improve the current prognostic assessment in lower respiratory tract infections. Other peptides share some features of hormokines, e.g. natriuretic peptide and copeptin. Hormokines are not only biomarkers of infection but are also pivotal inflammatory mediators. Like all mediators, their role during systemic infections is basically beneficial, possibly to combat invading microbes. However, at increased levels they can become harmful for their host. Multiple mechanisms of action were proposed. In several animal models the modulation and neutralisation of hormokines during infection was shown to improve survival, and thus might open new treatment options for severe infections, especially of the respiratory tract.

KEYWORDS: Antibiotics, hormones, pneumonia, sepsis

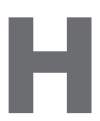
ormones are exclusively produced in endocrine cells and act systemically. Cytokines are produced by multiple cells and have local effects. "Hormokines" can follow either a classical hormonal expression or, upon inflammatory stimulation, show a more cytokinelike behaviour. The concept was based on the finding of a ubiquitous expression of peptides from the calcitonin (CT) family of genes during sepsis [1]. CT gene products (e.g. procalcitonin (PCT), CT gene-related peptides (CGRPs) and adrenomedullin) are a prototype of hormokine mediators: they can follow either a classical hormonal expression in neuroendocrine cells or, alternatively, a cytokine-like ubiquitous expression pathway in various cell types [1-5]. The ubiquitous inflammatory release can be induced either directly, via microbial toxins (e.g. endotoxin), or indirectly, via a humoral or cellmediated host response (e.g. interleukin (IL)-1 $\beta$, tumour necrosis factor (TNF)- $\alpha$ and IL-6). Parenchymal cells (including liver, kidney, adipocytes and muscle cells) provide the largest tissue mass and principal source of circulating hormokines in sepsis. The lowering of circulating hormokine levels by specific antibodies improves survival in various animal models, in different severities and time-points of mono- and polymicrobial sepsis [6, 7]. Based on these findings, a better understanding of the hormokine concept is important, as it holds experimental, diagnostic, prognostic and therapeutic promises.

\section{CALCITONIN PEPTIDES ARE PROTOTYPES OF HORMOKINES}

CT was discovered in the 1960s, when it was assumed to be a single hormone with an unknown role in human physiology $[8,9]$. Since then, it has been found to be only one entity among related circulating peptides that have pivotal roles in the metabolic and inflammatory host response to microbial infections [2]. CT peptides share their origin from a common ancestral gene (the CALC gene) and have
AFFILIATIONS

${ }^{*}$ Dept of Internal Medicine, University Hospital Basel, Basel, Switzerland.

CORRESPONDENCE

B. Müller

Dept of Internal Medicine

University Hospital Basel

Petersgraben 4

CH-4031 Basel

Switzerland

Fax: 41612655100

E-mail: happy.mueller@unibas.ch

Received:

December 202006

Accepted after revision:

March 152007

STATEMENT OF INTEREST

A Statement of interest for B. Müller

can be found at

www.erj.ersjournals.com/misc/

statements.shtml

European Respiratory Journal

Print ISSN 0903-1936

Online ISSN 1399-3003 
pronounced structural homologies (fig. 1). They include PCT, CGRP-I and -II, adrenomedullin and amylin, and their respective precursor peptides. With the exception of amylin, serum concentrations of all CT peptides are increased to variable extents during inflammation and infection [10-12]. PCT is a precursor peptide of the hormone CT and is also referred to as being the prototype of hormokine mediators [13]. After translation from CT mRNA, PCT is cleaved enzymatically into smaller peptides, to finally yield the 32-amino acid mature CT $[14,15]$. The CALC-I gene, by alternative processing of the primary RNA transcript, gives rise to two different socalled mature peptides: CT and CGRP-I [2]. In the absence of infection, the extra-neuroendocrine transcription of the CALCI gene is suppressed and is restricted to a selective expression in neuroendocrine cells. Mature CT is produced mostly in neuroendocrine C-cells of the thyroid and K-cells of the lung [16]. CGRP is also predominantly expressed in neuroendocrine cells, namely dorsal root ganglions and neurons clustered in the colon. In a similar manner to most neuroendocrine cells, the mature hormone is processed and stored in secretory granules $[2,5,13,16]$.

Administration of endotoxin to normal human volunteers increases serum PCT values to levels seen in sepsis and this increase persists for up to 7 days [17]. Several other proinflammatory mediators also induce PCT in vivo, e.g. TNF- $\alpha$, IL-2 and IL-6 [18]. Interestingly, patients with total or near-total thyroidectomy were also found to have detectable immunoreactive CT in the serum and urine [19], indicating an extrathyroidal origin. Accordingly, a microbial infection induces a massive and ubiquitous increase of CALC-I gene expression and a constitutive release of PCT from all parenchymal tissues and differentiated cell types throughout the body. This was shown in several mammal species, e.g. hamsters [1], pigs [20, 21], monkeys [22] and humans [5, 23]. Thus, under septic circumstances, the entire body could be viewed as being an endocrine gland. Interestingly, CGRP mRNA, the splice variant of the CALC-I gene, is also ubiquitously increased (fig. 2) [24]. Thus, the current authors postulated the presence of microbial infection-specific response elements within the CALC-I gene promoter, which, upon an inflammatory stimulus, override the tissue-selective expression pattern. Indeed, the transcriptional expression of CT mRNA is more uniformly upregulated in sepsis than the mRNAs of the classical cytokines [22]. Consequently, PCT levels increase several thousand-fold in severe systemic infections, i.e. sepsis, with a superior diagnostic accuracy as compared with other parameters of microbial infections $[25,26]$. The induction can be attenuated by cytokines that are also released during a viral infection (e.g. interferon (IFN)- $\gamma$ ) $[3,5]$.

Interestingly, no CT mRNA is found in leukocytes from septic patients and in peripheral blood mononuclear cell (PBMC)derived macrophages after incubation with Escherichia coli, lipopolysaccharide (LPS), IL-1 $\beta$ or TNF- $\alpha$ [3]. Ex vivo, the current authors observed only a transient expression of CT mRNA in monocytes for the initial $18 \mathrm{~h}$ of attachment to plastic dishes and differentiation into macrophages, resulting in a low-level release of PCT (in $42 \mathrm{~h}: \sim 20 \mathrm{ng} \cdot \mathrm{L}^{-1} ; \sim 0.1 \mathrm{fg} \cdot \mathrm{cell}^{-1}$ ) and higher amounts of the potent vasodilator CGRP $\left(80 \mathrm{ng} \cdot \mathrm{L}^{-1}\right.$
Genes

CALC-I

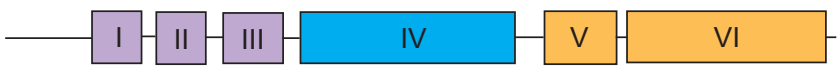

CALC-II

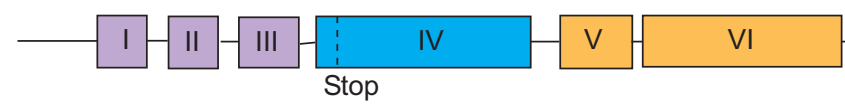

CALC-IV

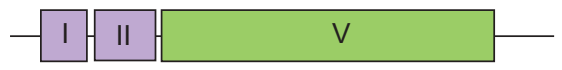

CALC-V

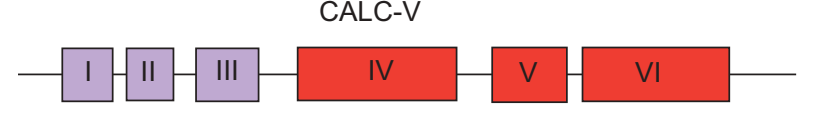

Peptides
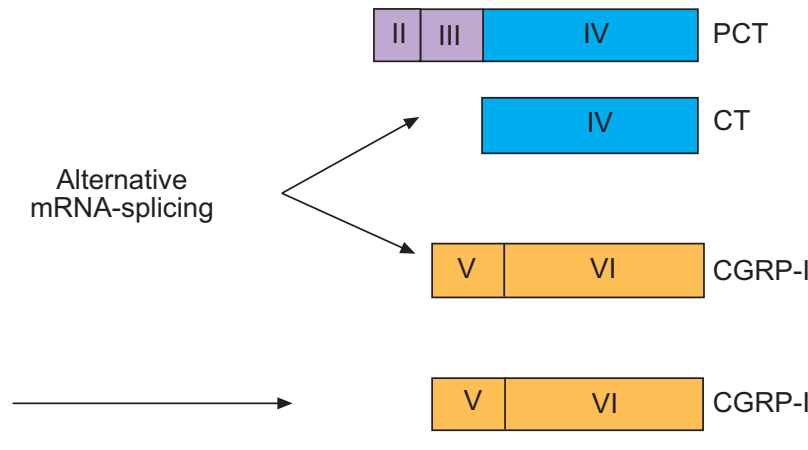

CGRP-I

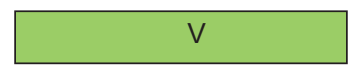

Amylin

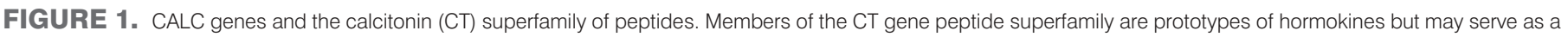

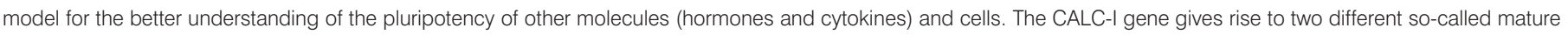

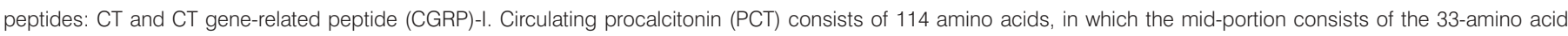

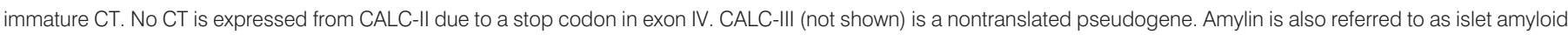

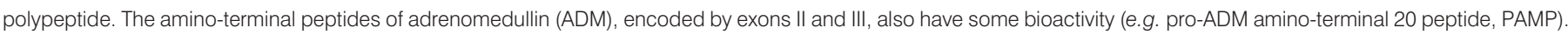
The common structural features and marked amino acid homology within the CT peptide superfamily suggest gene duplication of a common ancestral gene. 

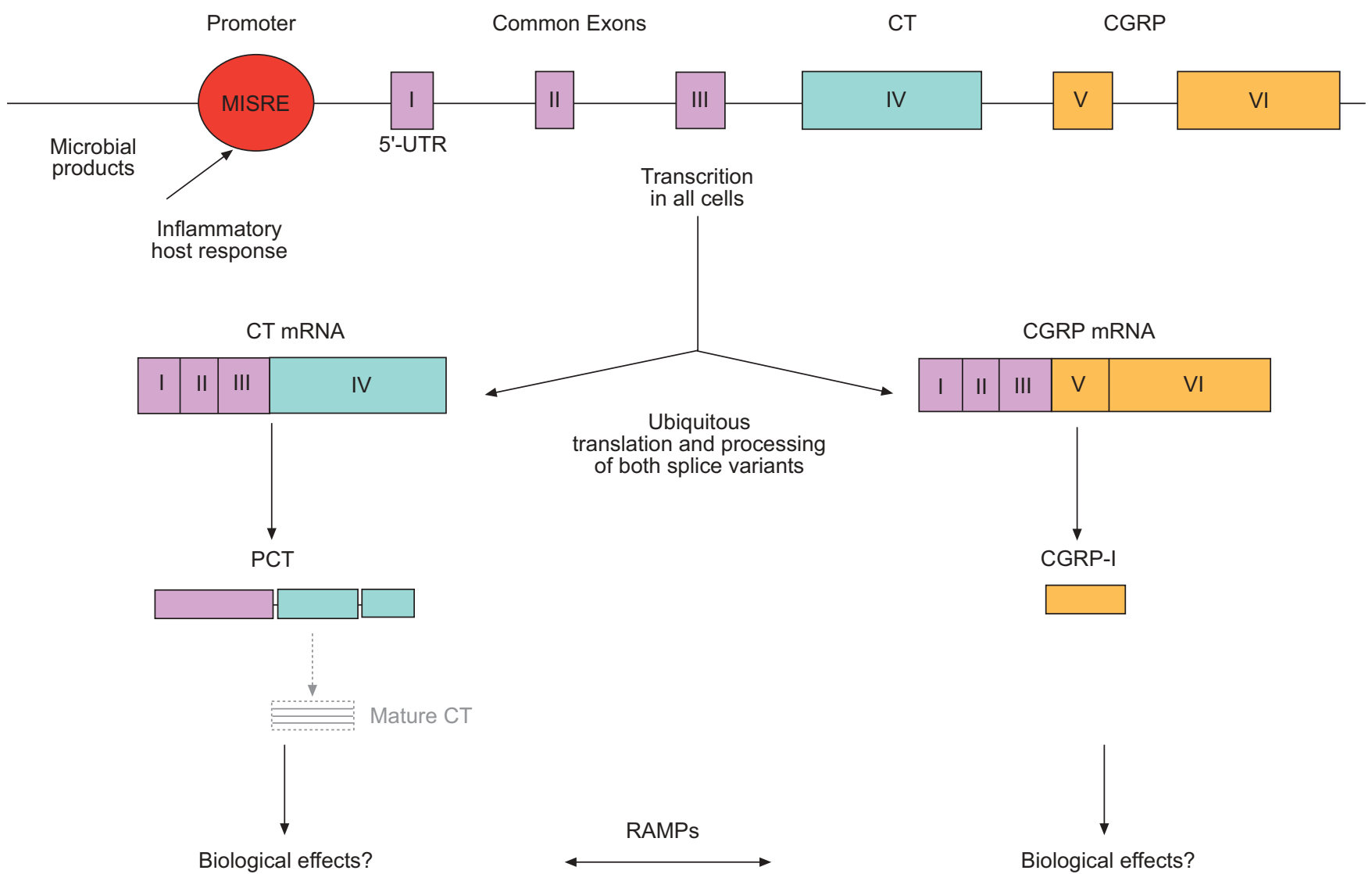

RAMPs

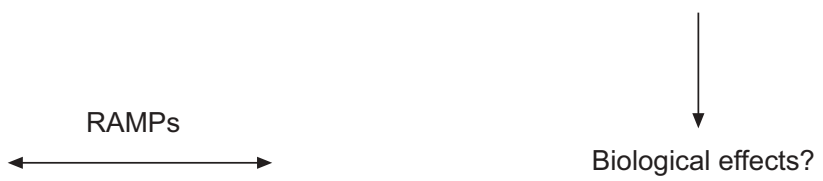

FIGURE 2. Schematic representation of the CALC-I gene. The presence of a microbial infection-specific transcriptional activation in many, if not all, cell types has been postulated. The presence of one or several stimulus-specific sepsis-response elements in the promoter could explain the specific transcriptional activation found in microbia infections. Calcitonin (CT) mRNA is the default splicing variant. CT gene-related peptide (CGRP) mRNA is spliced in the presence of a sepsis-inducible ubiquitous repressor. MISRE: microbial infection-specific response elements; UTR: untranslated region; PCT: procalcitonin; RAMP: receptor activity-modifying protein.

after $42 \mathrm{~h}$ ) [3]. Thereafter, both PCT and CGRP expression in macrophages became unresponsive towards stimulation by $E$. coli, LPS and/or pro-inflammatory cytokines [3]. Conversely, in co-culture experiments, these stimulated human macrophages were able to induce CT mRNA induction in adipocytes. Importantly, the differentiation status of parenchymal cells was also pivotal, for the inflammation-related expression of different CALC genes [4]. PCT and CGRP productions were induced by IL-1 $\beta$ and LPS in human mesenchymal stem cell (MSC)-derived mature adipocytes, but could not be induced in undifferentiated MSC nor in all dedifferentiated human tumour cell lines tested. In contrast, the expression of adrenomedullin, a product of the CALC-V gene, appears to be regulated differently: its expression occurred before and after adipogenic differentiation. IFN- $\gamma$ co-administration inhibited IL-1 $\beta$-mediated PCT and CGRP secretion by 78 and $34 \%$, respectively, but augmented IL-1 $\beta$-mediated adrenomedullin secretion by $50 \%$ [4]. CALC-I and -II mRNAs were induced by exogenous CGRP and adrenomedullin, suggesting a positive autocrine feedback loop within the expression of the CT peptide superfamily [3-5, 27]. Preliminary experimental evidence also suggests that this feedback loop is markedly enhanced by incubation with cycloheximide, an unspecific inhibitor of protein synthesis. This "superinduction" suggests the presence of one, or several, short-lived proteins, which suppress CALC gene expression in noninflamed nonneuroendocrine cells, i.e. as hormokine silencing factors.

Based on these experimental data, a trimodal expression pattern of the CALC-I gene and a closely regulated biphasic behaviour of infection-related PCT and CGRP secretion has been postulated (table 1 ) [3, 28]. In sepsis, the predominance of PCT as opposed to mature CT is indicative of a constitutive pathway within cells lacking secretory granules and, therefore, a bypassing of much of the enzymatic processing. Consequently, as is the case for most cytokines, there is little intracellular storage of PCT in sepsis [1]. The greater mRNA induction and peptide release from parenchymal cells in comparison to circulating cells appears to indicate a tissuebased, rather than leukocyte-based, mechanism of host defence, which is characteristic for hormokines. In the absence of infection, transcription of the CALC-I gene is restricted to a selective expression in endocrine cells found mainly in the thyroid. Therefore, CT hormone is synthesised constitutively, stored in secretory granules and released after appropriate cAMP-dependent stimulation, e.g. with gastrin [2].

What happens after the invasion of bacteria into the host organism? Both inflammatory and infectious stimuli lead to leukocyte recruitment to the site of infection, where they orchestrate the inflammatory reaction. In these blood-derived 
TABLE 1 Trimodal pattern of CALC-I gene expression occurring in neuroendocrine cells, parenchymal cells and monocytes

\begin{tabular}{|c|c|c|c|}
\hline & Thyroid & Parenchymal tissue & Monocytes \\
\hline \multirow[t]{2}{*}{ mRNA } & Constitutive & Regulated & Regulated \\
\hline & & Detectable after $>6 \mathrm{~h}$ & Detectable after $>2 \mathrm{~h}$ \\
\hline \multirow[t]{2}{*}{ Protein } & Regulated & Constitutive & Constitutive \\
\hline & & Detectable after $>10 \mathrm{~h}$ & Detectable after $>4 \mathrm{~h}$ \\
\hline Main function & Mature $\mathrm{CT}$, e.g. $\downarrow \mathrm{P}^{-\mathrm{Ca}^{2+}}$ & Sepsis-associated PCT increase & Local vasodilation (CGRP, PCT?) \\
\hline
\end{tabular}

monocytes and macrophages, PCT and CGRP release is only transient, occurs in very limited amounts and occurs exclusively during a short period following attachment of cells to the dilating endothelium while they are transmigrating to the site of infection. Conversely, microbial products (e.g. LPS) and/or pro-inflammatory mediators of the host response (e.g. IL-1 $\beta$ and TNF- $\alpha$ ) override the tissue-selective expression pattern in differentiated parenchymal cells. This is mediated by putative inflammation response elements within the CALC gene promoter [24]. A consecutive, ubiquitous and tissue-wide induction of CT mRNA leads to a massive secretion of several CT precursors, including PCT, into the circulation. Therefore, parenchymal organ-specific cells (e.g. adipocyte, liver, lung, brain and muscle cells, among others) and not white blood cells constitute the major source of infection-related PCT secretion, which may reach levels $>100,000$-fold above normal in sepsis. Increasing levels of PCT can be readily detected and could, therefore, aid in the clinical assessment of patients with suspected infections.

\section{ASSAYS TO MEASURE "PCT"}

It has been known for decades that infection, and especially sepsis, are associated with increased serum levels of immunoreactive calcitonin. This differs from the mature 32-amino acid CT peptide by its larger molecular weight and, hence, has been variously referred to as "large molecular weight calcitonin", "precalcitonin" or "big calcitonin" [29-32]. These peptides were also measurable in high levels in patients with small cell lung cancer and medullary thyroid cancer, where they have prognostic implications $[33,34]$. This large molecular weight material consists of several CT precursors [14, 35, 36]. Importantly, in patients with infection the extent to which any specific $\mathrm{CT}$ precursor peptide is increased relative to the others varies. For example, in sepsis the levels of CT:CTcarboxypeptide-I (CCP-I) and the aminoprocalcitonin (N-PCT) peptide may be even higher than the PCT values [14]. None of the assays presently in use measures the PCT molecule exclusively. Therefore, the current authors also used (and would prefer to use) the term "calcitonin precursors" to indicate, globally, the detected immunoreactive material. Those include PCT, N-PCT, CT:CCP-I, immature CT and CCP-I. This should be kept in mind when reading the literature, which almost exclusively refers to measurement of "procalcitonin" (PCT) in serum of infected patients [37-40].
For the diagnosis of infections, the diagnostic accuracy of PCT and its optimum cut-offs are completely dependent on the use of a sensitive assay in a pre-defined clinical setting. Ideally, an ultra-sensitive assay should reliably measure circulating concentrations of PCT in all healthy individuals. Such assays are currently available for research purposes (PCT-sensitive LIA ${ }_{\circledast}$ and N-PCT ${ }^{\mathrm{KLB}}$ ) and should be made widely available for the clinician in the near future. A rapid assay assures that results can be incorporated into clinical decision making.

The commercially available Kryptor ${ }_{\circledR}$ PCT assay (Brahms, Hennigsdorf, Germany) takes advantage of a time-resolved amplified cryptate emission technology. It is based on a sheep polyclonal anti-CT antibody and a monoclonal anti-katacalcin antibody, which bind to the $\mathrm{CT}$ and katacalcin sequence of $\mathrm{CT}$ precursor molecules. The assay has a functional assay sensitivity of $0.06 \mu \mathrm{g} \cdot \mathrm{L}^{-1}$, i.e. 3-10-fold above normal mean values [14]. The assay time is $19 \mathrm{~min}$ and in clinical routine results can be obtained within $1 \mathrm{~h}$ using 20-50 $\mu \mathrm{L}$ of plasma or serum [41]. Another commercially available two-site assay (LUMItest $\mathrm{PCT}$; Brahms), measures both PCT and the conjoined CT:CCP-I by means of a luminometer. This assay is useful in markedly detecting elevated PCT levels in severe, systemic bacterial infections, i.e. in sepsis. However, this manual assay has the disadvantage of a relative insensitivity, with an accurate detection limit of $\sim 0.3-0.5 \mu \mathrm{g} \cdot \mathrm{L}^{-1}[14,42]$. Thus, the LUMItest ${ }^{2}$ assay is not sensitive enough to detect mildly or moderately elevated PCT levels, which limits its diagnostic use in conditions other than overt sepsis. Virtually all published studies, with the exception of the current authors' intervention studies on antibiotic guidance, were performed using the LUMItest $\mathbb{B}$ assay. Due to the limited sensitivity, this assay should only be used with caution, if at all, when considering PCT for antibiotic guidance in or outside the intensive care unit (ICU). A colorimetric, "quick" bedside test (PCT $\mathrm{Q}$; Brahms) has the advantage of rapid determination of circulating PCT levels in $30 \mathrm{~min}$. Unfortunately, the assay is only semi-quantitative and is not sensitive enough to detect moderately elevated PCT levels [43].

\section{PCT IN THE DIAGNOSTIC ASSESSMENT OF SEVERE INFECTIONS}

Mortality in sepsis remains high, often due to delayed diagnosis and treatment. The traditional clinical signs of infection and the routine laboratory tests in sepsis (e.g. 
C-reactive protein (CRP) or white blood cell count) lack diagnostic accuracy and are sometimes misleading. In severe infection, most classical pro-inflammatory cytokines (e.g. TNF- $\alpha$, IL-1 $\beta$ or IL-6) are increased only briefly or intermittently, if at all. In view of this diagnostic and therapeutic dilemma, a more unequivocal test for the differential diagnosis of infection and sepsis is of paramount importance. Recently, in an attempt to improve current definitions of systemic inflammatory response syndrome and sepsis, it was suggested that PCT should be included as an additional diagnostic tool to improve and expedite the difficult clinical diagnosis [44]. This was also based on evidence from the literature that in sepsis, PCT levels increase several-fold until they are several thousand-fold greater, and on admission this increase often correlates with the severity of the condition and with subsequent mortality [45]. A variety of studies and reviews have shown the superior diagnostic accuracy of PCT as compared with other parameters for the diagnosis of sepsis, independent of the origin of infection (this data is summarised in $[1,45])$. Whereas the increase of other inflammatory markers such as CRP is attenuated by immunosuppressive medication (namely steroids), the diagnostic accuracy of PCT remains unaffected [46]. In addition, PCT seems to have a slight advantage over CRP because of its earlier increase upon infection and a better negative predictive value, as shown, for example, in children with fever of unknown origin [47] and adult patients with systemic inflammatory response in critical illness [25], trauma and surgery [48]. In a French pilot study, a blood PCT level $<0.5 \mathrm{ng} \cdot \mathrm{mL}^{-1}$ was prospectively used for the diagnosis of the viral origin of meningitis in 58 patients (aged 2 months to $14 \mathrm{yrs})$, in which enterovirus was isolated by culture or PCR during an outbreak (May-June 2000). On admission, 17 patients received antibiotic therapy. PCT dosage was routinely measured three times per week with the LUMItest $\circledast$. In nine patients, a PCT result $<0.5 \mathrm{ng} \cdot \mathrm{mL}^{-1}$ was obtained after $24 \mathrm{~h}$ and after $48 \mathrm{~h}$ in a further six: treatment was then stopped and the children left the hospital. Thus, PCT dosage allowed a decrease of hospitalisation time and a reduction of unnecessary antibiotic treatments. The study is important but was not powered to address its safety and external validity for widespread use [49].

The most frequent source of severe systemic infections are lower respiratory tract infections (LRTIs) [12]. A common problem in clinical practice is that, similar to sepsis, in respiratory tract infections the signs and symptoms of bacterial and viral infections are widely overlapping. After obtaining the medical history, physical examination, laboratory, and chest radiograph, the clinician is often left with considerable diagnostic uncertainty. In view of this diagnostic and therapeutic dilemma, a more reliable test for the differential diagnosis of bacterial respiratory tract infections in need of antibiotics from other respiratory disease would be extremely helpful [50].

In recent years, therefore, the current authors have investigated the ability of PCT and other hormones used as biomarkers to improve the clinical diagnosis, the prognostic assessment and therapeutic management of respiratory tract infections.

\section{PCT FOR ANTIBIOTIC STEWARDSHIP OF RESPIRATORY TRACT INFECTIONS}

LRTI, i.e. acute bronchitis, acute exacerbations of chronic obstructive pulmonary disease (COPD) or asthma, and community-acquired pneumonia (CAP), account for almost $10 \%$ of the worldwide burden of morbidity and mortality [51]. As much as $75 \%$ of all antibiotic doses are prescribed for acute respiratory tract infections, in spite of their predominantly viral aetiology. This excessive use of antibiotics is the main cause of the spread of antibiotic-resistant bacteria [52, 53]. Thus, decreasing the excess use of antibiotics is essential to combat the increase of antibiotic-resistant micro-organisms [54, 55]. A reduction of antibiotic use results in fewer side effects, lower costs, and, in the long term, leads to decreasing drug resistance. To limit antibiotic use, a rapid and accurate differentiation of clinically relevant bacterial LRTI from other, mostly viral, causes is pivotal $[56,57]$.

In this context, the current authors conceived and validated PCT-guided diagnosis and antibiotic stewardship using cut-off ranges in the continuum of LRTIs [51]. An algorithm developed at the University Hospital Basel (Basel, Switzerland), was used to classify the patients in the PCT group into four subgroups according to the probability of bacterial infection (fig. 3). The routine use of antimicrobial therapy was compared with PCT-guided antimicrobial treatment for LRTI. PCT was measured using a rapid assay with a functional sensitivity of $0.06 \mu \mathrm{g} \cdot \mathrm{L}^{-1}$ (Kryptor® PCT; Brahms). Results were routinely available within $1 \mathrm{~h}$ ( $24 \mathrm{~h}$ per day, 7 days per week).

In the PCT group, the physician was advised to follow the antibiotic treatment algorithm based on the PCT value and the likelihood of bacterial disease [1, 12, 58, 59]. In four now completed intervention trials enrolling $>1,200$ patients, the success of the intervention was measured by clinical outcomes, assuming that if the patient recovered without antibiotics then there was no serious bacterial illness [60-63]. This circumvented the problem of the nonexistent diagnostic "gold standard" based on traditional criteria (e.g. clinical signs, CRP, leukocytosis, culture result and allegedly favourable response to antibiotics also occurring in spontaneously resolving viral infections). PCT was chosen as the test marker because of its advantages over CRP and other inflammatory markers, namely an earlier increase upon infection, a better negative predictive value, and the unattenuated increase in the presence of immunosuppressive medication (e.g. steroids in patients with COPD) [46].

The ProRESP study assessed for the first time in a randomised intervention trial the capability of the PCT measurement in identifying bacterial LRTIs requiring antimicrobial treatment in the setting of an emergency department [60]. In this setting, the percentage of patients in the PCT group who had LRTI and received antibiotic therapy was reduced by almost $50 \%$, as compared with the standard group [60]. The clinical and laboratory outcome was similar in both groups. Reduced antibiotic use was most striking in acute bronchitis and acute exacerbations of COPD. COPD exacerbations offer a particular challenge in terms of diagnosing an infectious cause. Patients with COPD have an impaired pulmonary reserve and the infection might be locally restricted. Therefore, a PCT cut-off 

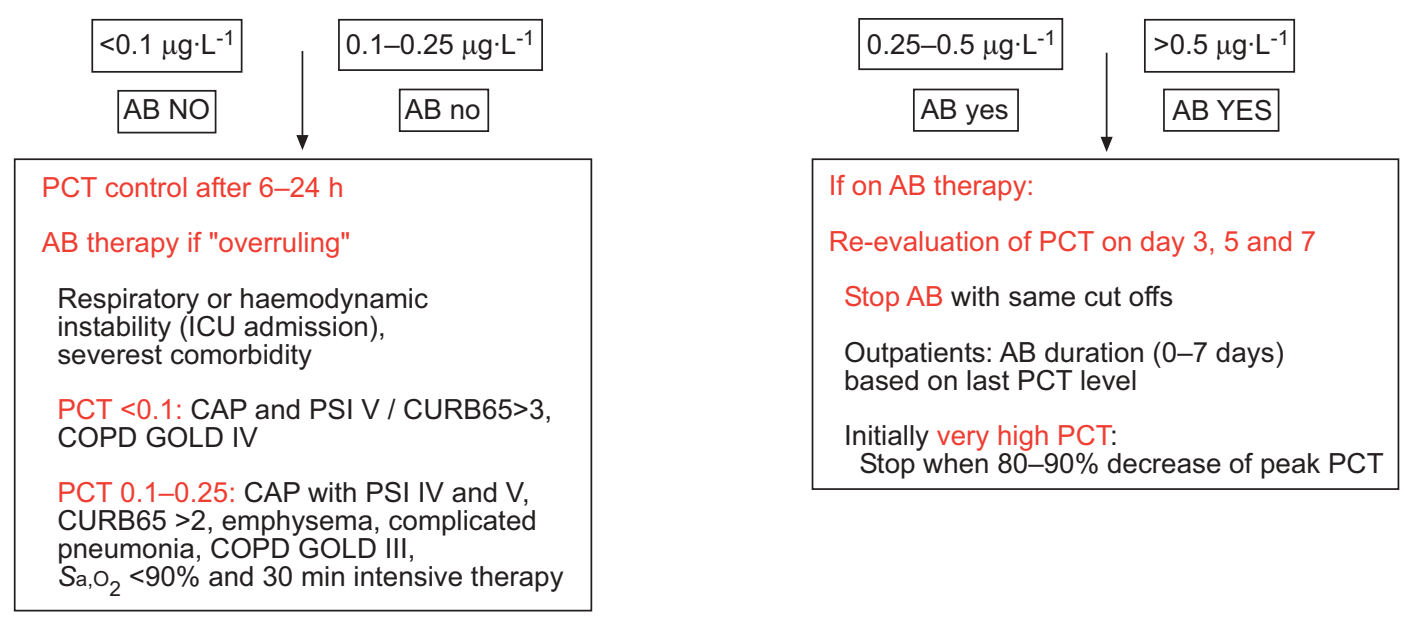

FIGURE 3. Procalcitonin (PCT)-guided antibiotic (AB) stewardship. Cut-off ranges of PCT were derived by calculating multilevel likelihood ratios and optimised for the setting of an emergency room and hospital. The use of a sensitive assay (Kryptor PCT; Brahms, Hennigsdorf, Germany) assured adequate sensitivity. Briefly, use of antibiotics was more or less discouraged $\left(<0.1 \mu \mathrm{g} \cdot \mathrm{L}^{-1}\right.$ or $\left.<0.25 \mu \mathrm{g} \cdot \mathrm{L}^{-1}\right)$ or encouraged $\left(>0.5 \mu \mathrm{g} \cdot \mathrm{L}^{-1}\right.$ or $\left.>0.25 \mu \mathrm{g} \cdot \mathrm{L}^{-1}\right)$ based on a range of PCT levels. The same cut-offs were used regardless of whether or not patients had been pre-treated with antibiotics prior to admission to the emergency department. In patients with very high PCT values on admission (e.g. $>10 \mu \mathrm{g} \cdot \mathrm{L}^{-1}$ ), discontinuation of antibiotic therapy was encouraged if levels decreased to $<80-90 \%$ of the initial value. In patients with an initial PCT level $>10 \mu \mathrm{g} \cdot \mathrm{L}^{-1}$ and smaller reductions during follow-up, continuation of antibiotic treatment was encouraged. Re-evaluation of the clinical status and measurement of serum PCT levels was recommended after 6-24 $\mathrm{h}$ in all persistently sick and hospitalised patients in whom antibiotics were withheld. As indicated above, the PCT algorithm should be overruled in patients with immediately life-threatening disease. However, in these patients, despite the immediate administration of intravenous broad-spectrum antibiotic therapy, a much more likely noninfectious differential diagnosis responsible for the critical illness must be strongly considered and actively sought, especially if PCT levels remain very low during follow-up. Physicians were advised that persistently elevated PCT levels may indicate a complicated course, while PCT levels may remain relatively low in localised infections (e.g. empyema or abscess). PCT levels were reassessed on days 3, 5 and 7 in hospitalised patients with ongoing antibiotic therapy, and in patients showing a worsening or delayed recovery of signs and symptoms, and antibiotic was discontinued using the PCT cut-offs defined above. For antibiotic stewardship in a medical or, especially, surgical intensive care unit (ICU), modified cut-off ranges might be necessary. Because mean PCT levels are increased in a cohort of critically ill patients as compared with patients in an emergency room or hospital setting, the optimal thresholds of the cut-off range are likely to be higher, especially in a immediately post-operative or post-traumatic situation. CAP: community-acquired pneumonia; PSI: pneumonia severity index; CURB65: severity score for CAP based on confusion, urea nitrogen, respiratory rate, blood pressure and age $\geqslant 65$ yrs; COPD: chronic obstructive pulmonary disease; GOLD: Global Initiative for Chronic Obstructive Lung Disease staging system for $\mathrm{COPD} ; \mathrm{Sa}_{1} \mathrm{O}_{2}$ : arterial oxygen saturation.

level for withholding antibiotics of $<0.1 \mu \mathrm{g} \cdot \mathrm{L}^{-1}$ is advisable in patients with severe disease and impaired pulmonary reserve. This was validated in the ProCOLD study, which included $>200$ patients [62]. At the index exacerbation, procalcitonin guidance reduced antibiotic prescription (40 versus $72 \%$; $\mathrm{p}<0.0001$ ) and antibiotic exposure (relative risk (RR) 0.56 , $95 \%$ confidence interval (CI) $0.43-0.73 ; \mathrm{p}<0.0001)$ compared with standard therapy. Moreover, PCT guidance at the index exacerbation allowed a sustained reduction in total antibiotic exposure for up to 6 months. Clinical outcome and improvement in forced expiratory volume in one second at 14 days and 6 months did not differ between groups. Within 6 months exacerbation rate, re-hospitalisation rate and time to next exacerbation were similar in both groups. Thus, PCT guidance for exacerbations of COPD offers a sustained advantage over standard therapy in reducing antibiotic use for up to 6 months, with a number needed to treat of three. The majority of COPD patients have positive sputum culture results, although these do not necessarily imply an active infection. In the PCT group, positive culture rates were similar in patients in whom antibiotics were given or withheld, as were outcomes, underlining the limited diagnostic usefulness of sputum cultures in COPD.

Pneumonia is defined as inflammation of the pulmonary parenchyma, which is often caused by a bacterial agent, mirrored in markedly elevated PCT levels. In the ProCAP study, to date the largest published interventional study, $>300$ patients were enrolled [64]. Herein, the concept of antibiotic stewardship by PCT was extended from a heterogeneous group of patients with LRTI to a larger cohort of patients with suspected CAP. These patients suffered from a severe bacterial infection and were more likely to experience an adverse outcome compared with patients with any type of LRTI. Accordingly, in bacterial CAP, delayed initiation of antibiotic therapy can be associated with an increased mortality [65]. Therefore, in the emergency management of suspected CAP, antibiotic therapy is rapidly initiated in all patients. In patients presenting with CAP, PCT levels were elevated, at $>0.1$ $0.25 \mu \mathrm{g} \cdot \mathrm{L}^{-1}$ in $\sim 80-90 \%$ of patients. Thus, the primary value of PCT in CAP is not to reduce antibiotic use on admission but to facilitate the differential diagnosis of new or progressing infiltrates (e.g. viral pneumonia, pulmonary embolism, malignancy, cryptogenic organising pneumonia and congestive heart failure, among others). Accordingly, PCT guidance could markedly lower the number of antibiotic courses in patients with infiltrates on chest radiograph unrelated to pneumonia.

The presence of nonbacterial diseases is usually suspected only after failure of antibiotic therapy, with the ensuing risks related to untreated, potentially life-threatening nonbacterial disease [66]. In self-limiting viral infections, cure of CAP under 
antibiotic therapy may be falsely considered as a proof of bacterial aetiology. In the PCT group, antibiotics were withheld in $15 \%$ of the patients with suspected CAP based on low PCT levels, confirming previous findings [60]. Importantly, in the ProCAP study all measures of clinical and laboratory outcome were similar in both groups. The uneventful course strongly argues against the presence of a clinically relevant bacterial infection in these patients. If a patient shows an infiltrate on chest radiograph in the presence of acute respiratory symptoms and repetitively low PCT levels, clinicians may consider "watchful waiting" or early discontinuation of antibiotic therapy, and actively seek an alternative diagnosis to bacterial pneumonia, which may include viral pneumonia, pulmonary embolism, malignancy, cryptogenic organising pneumonia and congestive heart failure, among others [67]. Conversely, in patients with diagnostic ambiguities, the finding of PCT levels of $>0.25-0.5 \mu \mathrm{g} \cdot \mathrm{L}^{-1}$ supports the clinician in the diagnosis of CAP.

Importantly, the optimal duration of antimicrobial therapy in CAP is largely unknown [68]. It is likely that it varies from patient to patient and is dependent on the severity of the diseases, the fitness of the host response and the underlying micro-organism, among other factors. Current guidelines recommend antibiotic courses of 7-14 days, depending on illness severity and the type of pathogen [69-71]. However, adherence to guidelines is variable [72] and physicians tend to treat for longer, especially in elderly patients with comorbidities and patients with severe CAP $[60,69]$. The duration of antibiotic therapy can be guided by clinical signs such as defervescence, decrease of sputum production and coughing, or improvement of the general condition. However, the interpretation of the clinical response lacks standardisation and validation, and is prone to interobserver variability [73]. Similarly, in $>70 \%$ of patients with CAP of presumed bacterial origin the causative microbe cannot be identified $[60,70,74$, 75]. Therefore, culture results are not considered central to the clinical care of this infection. This wide ambiguity of clinical symptoms and the high rate of negative culture results could explain the reluctance to stop antibiotic therapy early in routine clinical care, as reflected in the control group of a study carried out by the current authors [74]. PCT stewardship markedly reduced antibiotic exposure in patients with CAP, mainly by individually reducing the median duration of antibiotic courses from 12 to 5 days. In the PCT group, antibiotic courses were markedly shorter, as suggested by current guidelines $[72,76]$. Conversely, CAP is associated with adverse outcome, especially in bacteraemic patients, and thus longer antibiotic courses are recommended [77-79]. Accordingly, in the PCT group, antibiotic therapy was longer in bacteraemic patients with a median duration of $>10$ days.

In conclusion, in the emergency room and in hospitalised patients, PCT guidance leads to a more judicious antibiotic use in LRTI, mainly by lowering antibiotic prescription on admission in patients with acute and chronic bronchitis, and individual tailoring and earlier discontinuation of antibiotic therapy in patients with CAP, respectively. It is noteworthy that the vast majority of eligible patients agreed to participate in the current authors' studies, assuring applicability of the proposed approach under "real-life" conditions.
Acute respiratory infections are the most common reason for antibiotic therapy in primary care, despite their mainly viral aetiology. A PCT-guided diagnostic and therapeutic strategy for acute upper respiratory tract infections and LRTI in primary care is currently being evaluated [63].

To establish the study findings of the current authors as international standards of care, residual limitations have to be resolved. Three of the four studies were performed at a single university hospital, questioning the external validity. Standard care was used in the control group and the use of guidelines was not enforced. Only the study in primary care [63] as a noninferiority study had adequate power for outcome. However, the low rate of adverse events in an outpatients setting is arguably not representative for hospitalised patients and higher complication rates. Finally, in the ProCAP study, despite a marked reduction of duration of antibiotic therapy in the PCT group, overall length of stay in the hospital was not the target of intervention and was, therefore, similar. One argument is that once a patient is clinically stable and intravenous antibiotics are discontinued, discharge from the hospital should be safe, unless there are extenuating circumstances. In the USA, LRTI are estimated to be responsible for US\$15 billion per annum in direct treatment costs [80]. CAP is among the most common reasons for hospitalisation, especially in the elderly [81]. Patients with LRTI and comorbidities are often hospitalised with bronchitis and in the absence of an infiltrate. Conversely, most patients with respiratory tract infections and low risk of death prefer treatment outside the hospital [82]. Antibiotic use and the overall allocation of healthcare resources in LRTI is related to patients', nurses' and physicians' expectations and beliefs about the need and potential benefits [83]. Safe and multifocal strategies to reduce admission rate and the duration of hospitalisation will yield marked cost savings [84, 85]. These important questions in the context of LRTI are currently addressed in the large multicentre ProHOSP trial, which is ongoing [86].

\section{PCT IN VENTILATOR-ASSOCIATED PNEUMONIA}

Ventilator-associated pneumonia (VAP) is the most frequent nosocomial acquired infection in patients on mechanical ventilation [87]. Bacteriological cultures, including endotracheal aspirates, are helpful in the diagnosis of VAP; however, complete results are often not available $24-48 \mathrm{~h}$ after the sample has been taken. Recently, it has been shown that PCT levels can be used as complementary diagnostic markers for VAP [88] and are also a useful marker for diagnosing VAP in patients with an already-triggered acute phase response after successful cardiopulmonary resuscitation, where PCT levels were elevated a median of 2 days earlier than the clinical diagnosis of VAP [89]. PCT kinetics were also found to be helpful prognostic markers of VAP [90]. In some studies, however, the diagnostic accuracy of PCT for VAP has been challenged [90-93]. In contrast, soluble triggering receptor expressed on myeloid cells (sTREM-1) has been identified for diagnosis and outcome prediction in patients with sepsis, namely due to CAP and VAP. The problem is that any observational study investigating the diagnostic accuracy of a given marker is biased by the choice of the gold standard. In infections, this gold standard does not exist, and thus all studies are prone to a potential bias. Analysing circulating 
levels of sTREM-1 in the current authors' stored samples from the ProCAP intervention study revealed unexpected inaccuracies in sTREM-1 levels for the routine use of CAP [94]. Circulating sTREM-1 levels were not helpful for the assessment of aetiology and severity in patients with CAP or in predicting outcome of the disease. The current authors found no significant correlation between sTREM-1 levels, which were independent if assessed with the use of immunoblot technique or ELISA using several antibodies (from R\&D Systems, Minneapolis, MN, USA [91] and others), before and after ultracentrifuation, in plasma or serum, respectively. Similarly, sTREM-1 concentrations did not correlate with other markers of infection, i.e. $\mathrm{CRP}(\mathrm{r}=0.03 ; \mathrm{p}=\mathrm{NS}), \mathrm{PCT}(\mathrm{r}=-0.03 ; \mathrm{p}=\mathrm{NS})$ and leukocyte count $(\mathrm{r}=0.03 ; \mathrm{p}=\mathrm{NS})$. The negative findings of sTREM in critically ill patients with systemic inflammation and infections were independently confirmed by others [95]. Measurement of the local production of sTREM-1 in bronchoalveolar fluid might provide more reliable results [91]. However, this is not a cost-effective approach in patients with CAP and LRTI in general.

Interventional studies, in which the antimicrobial therapy is guided by PCT and in which the gold standard is the outcome, have the potential to resolve this dilemma [96]. In the context of VAP, such intervention studies are still lacking; this is also true for PCT. Here, a word of caution should be considered. The extent of the inflammatory contribution of the VAP infection per se (i.e. the signal) is very limited compared with the massive underlying systemic inflammatory response syndrome present in every intubated critically ill patient (i.e. the noise). The resulting lower signal-to-noise ratio in VAP will limit the diagnostic occuracy of biomarkers such as PCT.

\section{BIOMARKERS FOR THE PROGNOSTIC ASSESSMENT OF CAP}

In patients with $\mathrm{CAP}$, improved diagnostic assessment by PCT is important in order to differentiate from other noninfectious infiltrates and to guide the duration of antibiotics. It is also pivotal to being able to predict the prognosis of CAP and to estimate CAP severity for the purpose of guiding therapeutic options, such as the need for hospital or ICU admission, suitability for discharge, and choice and route of antimicrobial agents. Again, despite their widespread use in clinical routine, traditional markers, such as severity of disease assessment by the patient, fever, white blood cell count and also CRP are not reliable for the assessment of disease severity and mortality risk in CAP (table 2). The pneumonia severity index (PSI) is a widely accepted and validated severity scoring system that assesses the risk of mortality for pneumonia patients in a twostep algorithm, combining clinical signs, demographic data and laboratory values [97]. However, its complexity is high, jeopardising its dissemination and implementation, especially in everyday practice. Therefore, the CURB65 score has been proposed as a simpler alternative.

The dynamics of PCT levels have prognostic implications, as persistently elevated levels are associated with adverse outcome [98]. Conversely, decreasing PCT levels suggest a favourable outcome, usually showing a log-linear drop-off and a half life of 20-24 h [2]. The prognostic accuracy of PCT in the ICU can be markedly improved by considering the course of PCT. JENSEN et al. [99] analysed a total of 3,642 PCT measurements in 472 critically ill patients. The absolute PCT level, but especially the PCT increase for 1 day, was an independent predictor of 90-day all-cause mortality in the multivariate Cox regression analysis model. The adjusted hazard ratio for PCT increase for 1 day was 1.8 (95\% CI 1.3-2.7) and the RR for mortality in the ICU for patients with an increasing PCT was: 1.8 (1.4-2.4) after 1 days' increase; 2.2 (1.6-3.0) after 2 days' increase; and 2.8 (2.0-3.8) after 3 days' increase. Thus, a PCT increase during the course of disease was an independent predictor of all-cause mortality in a 90-day follow-up period after ICU admission. Mortality increased with every day that PCT increased. Levels of increases in CRP and white blood cell count did not seem to predict mortality. In the current authors' studies, PCT also showed a better prognostic accuracy compared with routinely measured parameters like CRP or leukocyte count, and has therefore been proposed as a marker of disease severity [64, 100]. However, there was a wide overlap in PCT levels between different severities of CAP (fig. 4) and only a small difference in PCT levels between survivors and nonsurvivors of CAP. Based on these data, PCT seems to be a reliable diagnostic marker that is able to guide decisions on antibiotic therapy, but not an ideal prognostic tool $[64,102]$.

Another member of the CALC gene family is adrenomedullin (fig. 1), which is one of the most potent vasodilating agents and has additional immune-modulating metabolic properties [4, 103-105]. Adrenomedullin also has a bactericidal activity, which is further enhanced by modulation of complement activity and regulation. Thus, it is not surprising that serum adrenomedullin levels were found to be elevated in sepsis [106]. The reliable measurement of adrenomedullin is challenging, since it is rapidly cleared from the circulation [103, 104]. The more stable mid-regional fragment of proadrenomedullin directly reflects levels of the rapidly degraded active peptide adrenomedullin [107].

In the current authors' study of $>300$ patients with CAP, proadrenomedullin levels measured on admission emerged as good predictors of severity and outcome of CAP, with a similar prognostic accuracy to the PSI and a better prognostic accuracy than commonly measured clinical and laboratory parameters (fig. 4). Importantly, it was found that proadrenomedullin levels could improve the prognostic accuracy of the PSI alone, acting as an additional margin of safety [64].

It is advisable to base the difficult task of prognostic assessment and treatment decisions on several parameters, rather than only one, with each mirroring different pathophysiological aspects. In this context, the current authors also evaluated the prognostic value of atrial natriuretic peptide (ANP), a member of the family of natriuretic peptides. ANP regulates a variety of physiological parameters, including diuresis and natriuresis, and reduces systemic blood pressure. Mature ANP is cleaved from carboxyl-terminal amino acids of the pro-hormone of ANP. The amino-terminal portion of the pro-hormone is secreted in the same molar ratio as ANP [108, 109]. Because of its longer half-life, the amino-terminal portion of pro-ANP, particularly the mid-region of this molecule (MRpro-ANP) has been shown to be a more reliable analyte [109]. In $\mathrm{CAP}$, the MR-pro-ANP level may mirror both the inflammatory cytokine response, correlated with the severity 


\begin{tabular}{|c|c|c|c|}
\hline \multirow[t]{2}{*}{ TABLE 2} & \multicolumn{3}{|c|}{$\begin{array}{l}\text { Evidence from intervention studies of respiratory } \\
\text { tract infections with procalcitonin (PCT)-guided } \\
\text { antibiotic (AB) therapy }\end{array}$} \\
\hline & ARTI & Bronchitis & Pneumonia \\
\hline Study & ProRESP & ProCOLD & ProCAP \\
\hline Setting & \multicolumn{2}{|c|}{ Emergency dept } & Hospital \\
\hline Design & \multicolumn{3}{|c|}{ Intervention studies } \\
\hline Patients n & 243 & 226 & 302 \\
\hline Median PCT $\mu \mathrm{g} \cdot \mathrm{L}^{-1}$ & 0.25 & 0.1 & 0.5 \\
\hline AB initiation $\downarrow \%$ & 44 & 40 & 14 \\
\hline Duration $\downarrow$ & & & 13 to 6 days \\
\hline Hospitalisation \% & 78 & 80 & 97 \\
\hline Adverse events \% & 10 & 16 & 20 \\
\hline \multicolumn{4}{|c|}{$\begin{array}{l}\text { In the ProRESP study, PCT guidance reduced AB prescription in } 243 \text { patients } \\
\text { with lower respiratory tract infections by almost } 50 \% \text { [19]. In the ProCAP study, } \\
\text { PCT-guided AB duration was shortened by } 65 \% \text { from } 12.9 \text { to } 5.8 \text { days, with a } \\
\text { similar outcome in patients with all severities of community-acquired } \\
\text { pneumonia [20]. In the ProCOLD study, the current authors demonstrated } \\
\text { long-term safety with a similar re-admission rate over } 6 \text { months in }>200 \text { acute } \\
\text { exacerbations of chronic obstructive pulmonary disease with markedly reduced } \\
\text { PCT-guided AB use [21]. ARTI: acute respiratory tract infection. }\end{array}$} \\
\hline
\end{tabular}

of pneumonia, as well as the presence of disease-relevant comorbidities, namely heart failure and renal dysfunction [110-113]. Therefore, the current authors investigated MR-proANP levels in a well-defined cohort of 545 consecutive patients with LRTI, in order to evaluate its prognostic use for the severity of disease and outcome; this study had two main findings [101]. First, plasma MR-pro-ANP levels were increased in LRTI, with the highest levels in CAP. Secondly, on admission, MR-pro-ANP levels were a better predictor of severity and outcome of CAP as compared with commonly measured clinical and laboratory parameters, and were comparable to the PSI. Similarly, in a cohort of patients with dyspnoea predominantly due to congestive heart failure, B-type natriuretic peptide was shown to be helpful for risk stratification in the subgroup of patients with CAP [114].

Vasopressin has haemodynamic as well as osmoregulatory effects and reflects the individual stress response. Copeptin is co-synthesised with vasopressin, directly mirroring vasopressin levels, but is more stable in plasma and serum. Both levels are increased in patients with septic shock [115]. Copeptin levels were significantly higher in patients with LRTI as compared with controls $(\mathrm{p}<0.001)$, with the highest levels in patients with CAP [116]. Copeptin levels increased with increasing severity of CAP, as classified by PSI $(p<0.001)$. In patients who died, copeptin levels on admission were significantly higher as compared with levels in survivors. The area under the receiver operating curve for survival was significantly higher for copeptin, as compared with CRP and leukocyte count, but was similar to that of PCT. Recently, in patients with acute exacerbations of COPD, copeptin was shown to be predictive for long-term clinical failure, independent of age, comorbidity, hypoxaemia and lung functional impairment in multivariate analysis [117]. The combination of copeptin and previous hospitalisation for COPD increased the risk of poor outcome.

Thus, proadrenomedullin, natriuretic peptides, copeptin and other, as yet unevaluated, biomarkers can be helpful in the risk stratification of patients with CAP and LRTI in general. Various easy-to-determine surrogate biomarkers have been proposed to predict disease severity in CAP patients, thereby aiming to complement the PSI score [100, 116, 118, 119].

Of course, biomarkers will always oversimplify the interpretation of important variables and, therefore, biomarkers are meant to complement, rather than to supersede, the judgment of clinicians and/or validated severity scores. Conceptually, the likelihood of an adverse outcome should determine the medical indication, length of hospitalisation and allocation of healthcare resources. The additional value of these novel biomarkers in the careful clinical assessment is currently being validated in the ProHOSP study in a large cohort of patients [86].

\section{BIOMARKERS FOR PROGNOSTIC ASSESSMENT IN SEPSIS}

The development of a septic infection is a continuum and, in the majority of cases, a sequelae of LRTI. A reliable prognostic assessment is crucial not only in CAP but equally in sepsis. Sepsis is the leading cause of death in critically ill patients in the USA. It develops in 750,000 people annually, and more than 210,000 of them die $[120,121]$. Roughly $9 \%$ of patients with sepsis progress to severe sepsis and $3 \%$ progress to septic shock [122]. Early and adequate diagnosis and risk assessment is pivotal for the optimised care of critically ill patients. The acute physiology and chronic health evaluation (APACHE) II score as a prognostic scoring system in sepsis was originally not recommended for individual outcome prediction in sepsis patients [123]. However, despite its inherent limitations, outcome predictors are clearly helpful in identifying those septic patients with a high risk of death, who are more likely to benefit from intervention treatment.

In an attempt to improve current sepsis definitions, in the "PIRO" (predisposition, insult infection, response, organ dysfunction) concept the use of readily measurable circulating biomarkers is recommended as an additional tool for the timely assessment and severity classification of septic patients and the prediction of mortality [44].

The current authors have shown that proadrenomedullin has a similar prognostic accuracy as compared with the APACHE II score [102]. This also validates its prognostic usefulness in patients with CAP [64]. Upon availability in the routine setting, proadrenomedullin might prove to be an additional, helpful tool for a broader prognostic classification of infected patients, both in- and outside of the ICU. Two main mechanisms might be responsible for the marked increase of circulating midregional proadrenomedullin and mature adrenomedullin in sepsis. Firstly, as a member of the CALC gene family, adrenomedullin is widely expressed and extensively synthesised during sepsis, in a similar manner to other calcitonin peptides, namely PCT and calcitonin-gene related peptides [2] Bacterial endotoxins and pro-inflammatory cytokines upregulate adrenomedullin gene expression in many tissues both in vitro and in vivo in rodents and humans [4]. In addition, a 

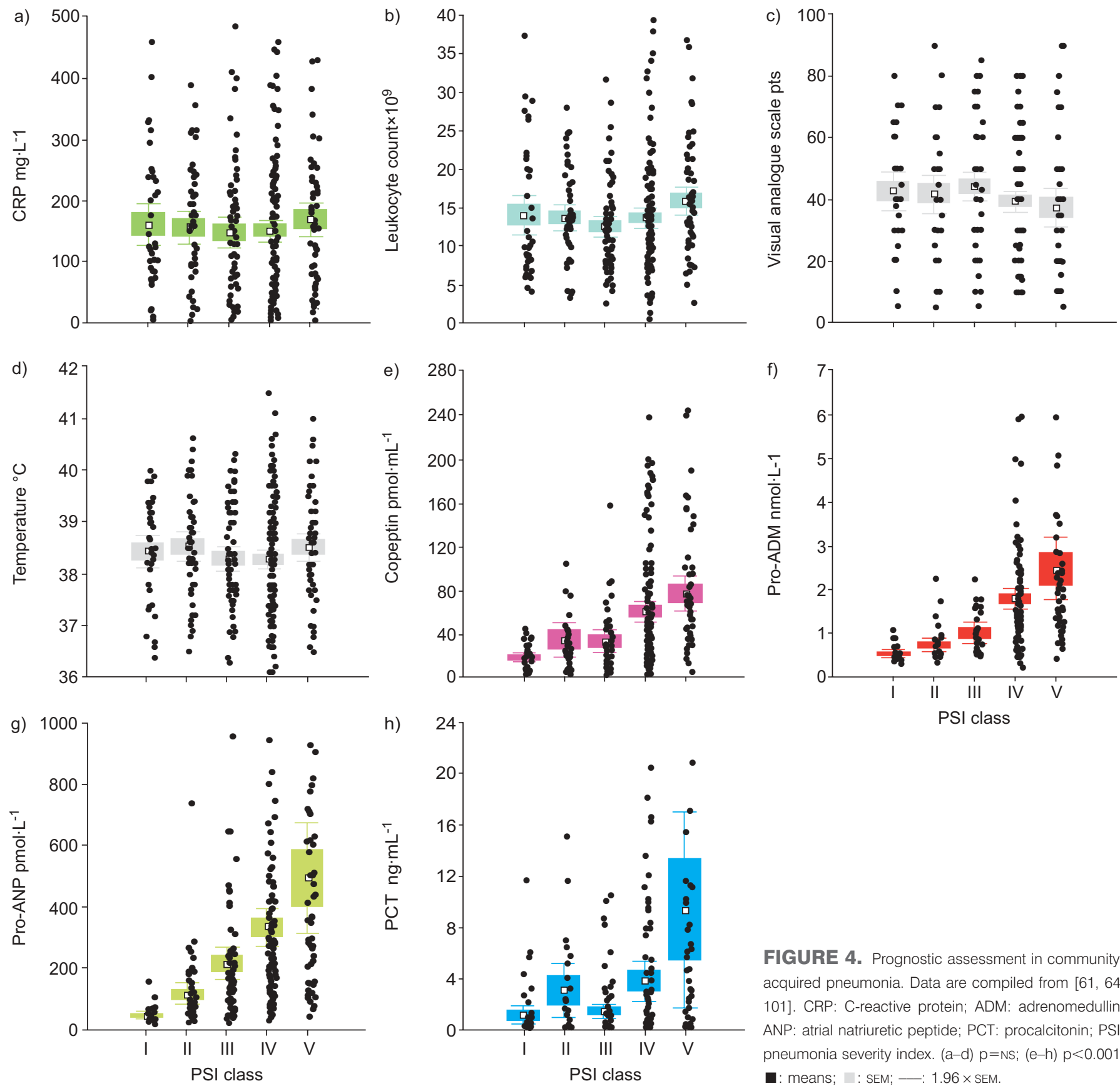

FIGURE 4. Prognostic assessment in communityacquired pneumonia. Data are compiled from [61, 64 101]. CRP: C-reactive protein; ADM: adrenomedullin ANP: atrial natriuretic peptide; PCT: procalcitonin; PSI: pneumonia severity index. (a-d) $p=N S$; (e-h) $p<0.001$ 口: means; 1 : SEM; —: $1.96 \times$ SEM

decreased clearance by the kidneys may be responsible in part for the increased levels in sepsis [106].

Similarly, the current authors evaluated the same biomarkers as in CAP, which were all higher in nonsurvivors compared with survivors and had a similar accuracy for the prediction of death to the APACHE II score [107, 108, 115, 124-126].

Importantly, no biomarker is a substitute for a careful clinical assessment and the obtainment of appropriate cultures in all patients. However, used appropriately, biomarkers allow an earlier diagnosis of infections and can inform physicians about the course and prognosis of the disease better than more routinely used clinical and laboratory markers.

\section{THE CENTRAL ROLE OF HORMOKINES IN HOST DEFENCE}

Sepsis is a catastrophic consequence of overriding inflammation, insufficient host defence and metabolic disturbances. To better understand the role of PCT in the sepsis cascade, the relationship to the proximal pro-inflammatory mediators, IL-1 $\beta$ and TNF- $\alpha$, was examined in hamster sepsis. PCT did not initiate or enhance IL-1 $\beta$ or TNF- $\alpha$ expression; however, the massive and sustained elevation of PCT seen in hamster sepsis was induced by the proximal cytokine, TNF- $\alpha$ [127]. Thus, PCT is a secondary mediator, which may augment and amplify, rather than initiate, the septic response. In addition, PCT might induce the synthesis of inflammatory cytokines by human 
PBMCs [128]. Induction was moderate, but specific, as the effect was not seen with administration of N-PCT or CCP-1, two breakdown products of PCT. PCT is a modulator of cytokine-induced inducible nitric oxide synthase expression in rat vascular smooth muscle cells, with a maximal suppressing effect on nitric oxide (NO) synthesis at PCT levels of $100 \mathrm{ng} \cdot \mathrm{mL}^{-1}$ [129]. However, at the highest concentration utilised $\left(5 \mathrm{mg} \cdot \mathrm{L}^{-1}\right)$, PCT did not inhibit NO production and had no effect on unstimulated cells. Recent findings suggest a less prominent role of $\mathrm{NO}$ in human physiology and metabolism, as compared with rodents [27, 130].

Based on the decrease of circulating calcium induced by mature $\mathrm{CT}$, a role of PCT in the disordered calcium homeostasis of critically ill patients was postulated [45]. Both total and ionised hypocalcaemia correlated negatively with the increase of circulating PCT and were also more pronounced with increasing severity of infection. Notably, serum levels of mature CT were normal in sepsis. Thus, in humans, PCT may also play a role in the development of inflammatory hypocalcaemia in vivo, although causal relationships cannot be reliably drawn from correlation of findings in observational studies. Conversely, in hamsters, the injection of PCT neutralised the acute calcium-lowering effects of $\mathrm{CT}$, indicating species-specific differences [131].

Other hormokines appear to be important in humans with infections. In sepsis, mRNAs for CGRP-I, CGRP-II and adrenomedullin also appear to be ubiquitously expressed [132]. Accordingly, in humans, circulating levels of CGRPs and adrenomedullin have also been found to be elevated in microbial infections [10, 11, 106, 133]. How do these hormokines of the CALC gene family of peptides possibly mediate their effects?

CGRP and adrenomedullin are potent vasodilators during septic shock [134]. The LPS-triggered release of CGRP is NOand prostaglandin-dependent [135]. Both CGRP and adrenomedullin have immune-modulating, metabolic and vascular actions [2], which are NO [136, 137], nuclear factor-kB [138], cAMP and calcium mediated [139]. CGRP-I, CGRP-II and adrenomedullin are considered to be auto- and/or paracrine factors in many tissues. In sepsis, a competition arises between organs for reduced systemic blood pressure and blood flow. With their very potent vasodilating properties, the tissue-wide production of CGRPs and adrenomedullin assures blood supply to the individual organs. Thus, in a teleological perspective, due to their vasodilatory properties, the tissue-wide production of CGRP and adrenomedullin assures blood supply to the individual tissues, and thereby may oppose vasoconstrictory effects of other stress hormones released during sepsis (e.g. catecholamines and cortisol). Detrimental septic shock might be the ultimate, disastrous outcome of this powerful action.

Interestingly, adrenomedullin also has a potent direct bactericidal activity $[140,141]$. The adrenomedullin (CALC-V) gene also undergoes alternative splicing, similar to the CALC-I gene, where it yields PCT and CGRP (fig. 1). Toll-like receptor (TLR)4 is involved in LPS-dependent adrenomedullin induction, as it is not found in TLR4 mutant mice after exposure to LPS [142]. The shortest mRNA form of adrenomedullin includes exon I-IV and generates adrenomedullin (located on exon IV) and an aminoterminal peptide fragment, proadrenomedullin amino-terminal
20 peptide (PAMP), which is encoded in exons II and III. In a longer mRNA form, an early stop codon omits translation of adrenomedullin, hence, only PAMP is produced [7]. An antimicrobial effect of adrenomedullin, and especially for PAMP, against E. coli has been described [141, 143]. The amino-terminal structure of adrenomedullin is responsible for this activity [144]. In addition, adrenomedullin binds short consensus repeats of factor $\mathrm{H}$ (also termed adrenomedullinbinding protein-1) and has complementary regulatory activity [144]. Factor $\mathrm{H}$ prevents $\mathrm{C} 3$ activation by the alternative pathway, it protects host cells from attack by binding to surface-bound $\mathrm{C} 3 \mathrm{~b}$ and it thereby accelerates decay of $\mathrm{C} 3$ convertase and suppresses complementary activation. Adrenomedullin is expected to enhance complementary activation by interfering with factor $\mathrm{H}$ activity and, thereby, strengthening the antibacterial defence [7]. The binding of adrenomedullin to factor $\mathrm{H}$ protects it against degradation [145]. Thus, the adrenomedullin-factor $\mathrm{H}$ complex regulates the bioactivity and half-life of both molecules.

\section{HOW DO HORMOKINES MEDIATE THEIR EFFECTS?}

Based on the structural homologies, different CT peptides have overlapping bioactivities, exerted by binding to the same family of receptors (fig. 5 and table 3) [2, 146].

There are two subgroups of these $\mathrm{G}$ protein-coupled receptors: $\mathrm{CT}$ receptors (CR) and $\mathrm{CT}$ receptor-like receptors (CRLR). Three accessory proteins, receptor activity-modifying protein (RAMP)-1, -2 and -3, alter their ligand affinity and responsiveness. For example, CRLR/RAMP-1 forms a CGRP-I or

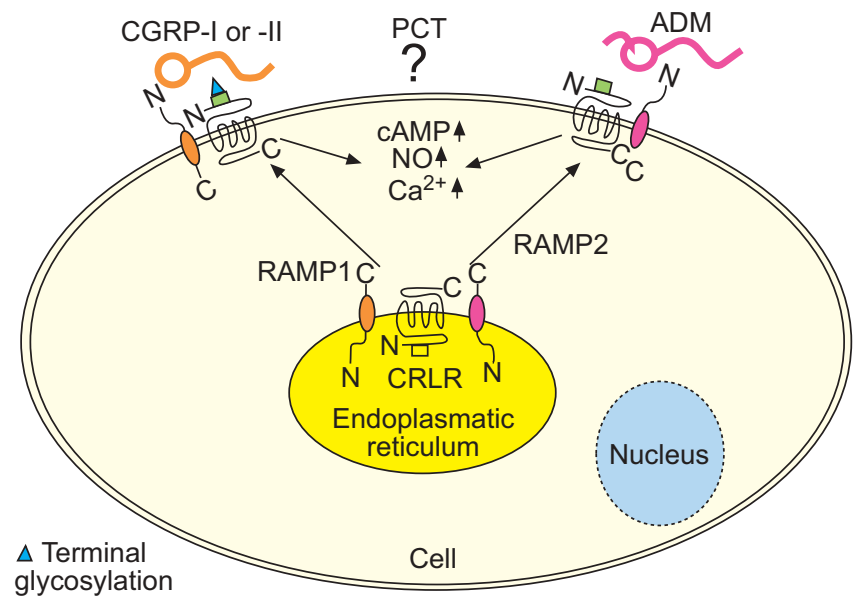

FIGURE 5. Receptors for calcitonin (CT) peptides. Based on the structural homologies, different CT peptides have overlapping bioactivities, which they exert by binding to the same family of receptors [16]. There are two subgroups of these $G$ protein-coupled receptors with seven transmembrane domains: CT receptors and CT receptor-like receptors (CRLR). Three accessory proteins, which are called receptor activity-modifying proteins (RAMP-1, -2 and -3), act upon these receptors, thus altering their specific responsiveness and ligand affinity, and hence modifying the physiological profile of the CT-peptide superfamily [146]. Depending on which of the different RAMPs is associated with the receptor, each member of the CTgene family of peptides binds with differing affinities. Whether procalcitonin (PCT) and other CT precursor peptides from the other CALC genes are also ligand for these receptors is currently unknown. CGRP: calcitonin gene-related peptide; ADM: adrenomedullin; NO: nitric oxide; N: amino terminal; C: carboxyl terminal. 


\begin{tabular}{|c|c|c|c|c|}
\hline \multirow[t]{2}{*}{ TABLE 3} & \multicolumn{4}{|c|}{$\begin{array}{l}\text { alcitonin (CT) peptides, as hormokines, are a } \\
\text { inctional entity }\end{array}$} \\
\hline & CT & CGRPs & Amylin & ADM \\
\hline Receptor & $\mathrm{CR}$ & CRLR & $\mathrm{CR}$ & CRLR \\
\hline RAMP & $(2)^{\#}$ & 1 & 1 or 3 & 2 or 3 \\
\hline Second messenger & CAMP, $\mathrm{Ca}^{2+}$ & NO & $?$ & $\mathrm{NO}, \mathrm{NF}-\mathrm{kB}$ \\
\hline \multicolumn{5}{|l|}{ Metabolic effects } \\
\hline Insulin resistance & - & + & + & - \\
\hline Effect on $\beta$-cells & \pm & + & + & - \\
\hline Anorectic & ++ & + & + & + \\
\hline Gastric protection & - & + & + & - \\
\hline $\begin{array}{l}\text { Effects on calcium/ } \\
\text { bone }\end{array}$ & ++ & \pm & + & \pm \\
\hline \multicolumn{5}{|l|}{ Inflammatory effects } \\
\hline $\begin{array}{l}\text { Increase plasma in } \\
\text { infections }\end{array}$ & РСT & + & With insulin & + \\
\hline Toxic in sepsis & РCT & $+?$ & - & $+?$ \\
\hline Vasodilation & \pm & +r+t & + & ++ \\
\hline Pro-inflammatory & \pm & ++ & - & + \\
\hline Thermoregulation & - & + & + & + \\
\hline $\begin{array}{c}\text { Chrono- and } \\
\text { ionotropic }\end{array}$ & - & + & + & + \\
\hline Analgesic & ++ & - & + & - \\
\hline \multicolumn{5}{|l|}{ Host defence } \\
\hline Bactericidal activity & $?$ & - & - & ++ \\
\hline
\end{tabular}

Data represent predominantly experimental results obtained in vitro or in animals (mostly rodents) using supra-physiological dosages. The 114-amino acid form of human procalcitonin (PCT), circulating in high levels during sepsis, is not yet available for experimental purposes. +: positive effect; -: negative effect; \pm : mixed effect; + ?: questionable positive effect; ?: questionable effect; +t: clear positive effect; ++1+: powerful effect. CGRP: CT gene-related peptide; ADM: adrenomedullin; CR: CT receptors; CRLR: CT receptor-like receptors; RAMP: receptor activity-modifying protein; $\mathrm{Ca}^{2+}$ : calcium homeostasis NF: nuclear factor. ${ }^{\#}$ : not on absolute prerequisite for function of the colcitonin receptor. Compiled and adapted from [2].

-II-responsive cell and co-expression of RAMP-2 with CRLR yields adrenomedullin responsiveness. CR, with or without RAMP 2, is a CT receptor, RAMP-3 an amylin receptor and RAMP-1 a combined amylin/CGRP receptor. It is not known whether PCT also binds to CR or CRLR, probably with low affinity, or has an "own" receptor mediating distinct effects. It is tempting to speculate that the extraordinary increase of circulating PCT in sepsis prevents CGRP and adrenomedullin from exerting their actions, and thus acts as a competitive antagonist.

Three main circulating peptide fragments of PCT have been identified [14], including N-PCT. N-PCT is also markedly elevated in sepsis and shares a structural similarity in the amino-terminal end with adrenomedullin, suggesting a bactericidal potential for PCT.

\section{HORMOKINES AS THERAPEUTIC TARGET IN SEVERE INFECTIONS}

Conceptually, two therapeutic targets for hormokines could be postulated. Firstly, the antimicrobial properties of hormokines, especially adrenomedullin and PAMP, might be used to develop new antibiotics. The finding of high levels during bacterial infections in body fluids (plasma, sweat, milk, saliva, amniotic fluid and others) also point to a role in the systemic immune defence. Epithelial structures represent the first barrier against pathogenic infections. In mammals, hormokines are produced, like many other endogenous antimicrobial peptides, by mucosal epithelia. The accumulation of hormokines, namely adrenomedullin, in epithelia surfaces (skin, lung, genitourinary tract, digestive system and others) indicates a role in the mucosal defence mechanism [147]. The digestive tract in particular is colonised by billions of allegedly harmful micro-organisms and only their preservation within the intestinal lumen prevents microbial invasion and lethal damage to the host. In this perspective, every food intake is a major challenge, as digested micronutrients have to be absorbed from the extremely contaminated environment of the intestinal lumen into the sterile circulation. It is tempting to speculate that hormokines might be an evolutionary tool to protect the organism from bacterial sepsis after food intake. It is interesting that the release of several members of the hormokine family are triggered by and linked to the release of gastro-intestinal hormones during food intake (e.g. CT by (penta)gastrin and amylin to insulin).

In addition, following the principle "sola dosis facit venenum", very high concentrations of endogenously produced hormokines will become toxic to the host. Conceptually, potent mediators like CGRP or adrenomedullin are tightly regulated; circulating levels are kept within a very narrow range in order to prevent harmful excessive effects. Hence, in sepsis, circulating levels of CGRP are only modestly elevated, prohibiting its use as a diagnostic tool. In contrast, circulating levels of PCT are greatly, i.e. up to 1 million-fold, increased in sepsis [12]. The fact that the organism is able to survive a several thousand-fold increase of PCT suggests an attenuated form and strength of action. This wider "therapeutic range" is arguably an advantage for iatrogenic modulation, which is mostly less coordinated compared with endogenous feedback regulation. Several other characteristics favour the "less potent" PCT as a therapeutic target in sepsis. The toxic effects of PCT are restricted to an inflamed organism: injection of human PCT to septic hamsters with peritonitis doubled their death rate [148]. In contrast, in healthy animals the administration of similar doses of PCT did not show any detrimental effects. In contrast to the transiently increased classical cytokines, for which immunoneutralisation trials in humans have been disappointing, the massive increase of circulating PCT persists for several days [17]. Circulating PCT is virtually always and persistently increased for several days in bacteraemic sepsis; its onset is early $(\leqslant 3 \mathrm{~h})$ and it can be easily measured as a mid-to-late mediator. The resulting superior diagnostic accuracy could greatly improve patient selection and stratification for clinical studies. Importantly, administration of PCT to septic hamsters with peritonitis doubled their death rate [148]. Conversely, treatment with PCT-reactive antiserum increased survival of septic hamsters and pigs with mono- and polymicrobial sepsis [6, 21, 148]. A 1-h i.v. immunoneutralisation of porcine PCT improved all vital parameters of septic pigs: it increased short-term survival from 0 to $80 \%$ and was effective even when administered after 
the animals were moribund $[6,7,149]$. These features are not shared by any other known molecule.

In spite of these important findings, there is currently a paucity of knowledge of underlying pathophysiological concepts. Data on the molecular mechanisms mediating these effects are scarce. Clearly, a better understanding of the mechanisms underlying the regulation and function of CT peptides as hormokines is original, physiopathologically interesting and clinically important $[1,16]$.

\section{CONCLUSION}

In conclusion, when used in conjunction with an optimal clinical assessment, biomarkers can improve the diagnostic and prognostic assessment of sepsis and its precursors (i.e. LRTIs, including pneumonia). Both strengths and weaknesses of biomarkers must be considered for a rational and safe implementation in a routine clinical setting. The time has come to move beyond the observational reporting of "promising" biomarkers [150]. Specific cut-off ranges must be proposed and intervention studies conducted to tackle the existing vicious cycle of antibiotic overuse, emerging multiresistance and unnecessary allocation of healthcare resources. Only this will open our eyes and reveal whether biomarkers can really help us in the routine care of patients with LRTIs and, ultimately, sites of infection other than the lung.

Elevated serum PCT levels correlate with presence, course and outcome of sepsis in humans. As a marker, PCT is not perfect, but is reliable enough to steward and reduce antibiotic (over)use in respiratory tract infections. No marker other than PCT has been rigorously assessed in intervention studies for its capability to be used safely for antibiotic stewardship in LRTIs, the ultimate proof of its diagnostic accuracy.

Importantly, biomarkers can also improve the prognostic assessment of sepsis and pneumonia to predict failure compared with other routinely used laboratory parameters or compared with a clinical assessment alone.

Several characteristics of hormokines favour these molecules as a therapeutic target in sepsis.

Calcitonin gene-related peptide and adrenomedullin are potent immune-modulating and vasoactive peptides. Adrenomedullin has antibacterial activity. Procalcitonin is very frequently increased in bacterial infections, its onset is early, and the diagnostic accuracy of the measurement should greatly improve patient selection for any study of the therapeutic efficacy of antibiotic therapy. Because of its sustained and massive increase, procalcitonin, and possibly other hormokines, provides an ideal therapeutic immunoneutralisation target for sepsis in humans. The proof of principle has been successfully shown for procalcitonin in several animal and infectious disease models. These features are not matched by any other known molecules, and the therapeutic promise needs to be further explored.

\section{REFERENCES}

1 Muller B, Becker KL. Procalcitonin: how a hormone became a marker and mediator of sepsis. Swiss Med Wkly 2001; 131: 595-602.
2 Becker KL, Nylen ES, White JC, Muller B, Snider RH Jr. Procalcitonin and the calcitonin gene family of peptides in inflammation, infection, and sepsis: a journey from calcitonin back to its precursors. J Clin Endocrinol Metab 2004; 89: 1512-1525.

3 Linscheid P, Seboek D, Schaer DJ, Zulewski H, Keller U, Muller B. Expression and secretion of procalcitonin and calcitonin gene-related peptide by adherent monocytes and by macrophage-activated adipocytes. Crit Care Med 2004; 32: 1715-1721.

4 Linscheid P, Seboek D, Zulewski H, Keller U, Muller B. Autocrine/paracrine role of inflammation-mediated calcitonin gene-related peptide and adrenomedullin expression in human adipose tissue. Endocrinology 2005; 146: 2699-2708.

5 Linscheid P, Seboek D, Nylen ES, et al. In vitro and in vivo calcitonin I gene expression in parenchymal cells: a novel product of human adipose tissue. Endocrinology 2003; 144: 5578-5584.

6 Becker KL, Nylen ES, Snider RH, Muller B, White JC. Immunoneutralization of procalcitonin as therapy of sepsis. J Endotoxin Res 2003; 9: 367-374.

7 Zudaire E, Portal-Nunez S, Cuttitta F. The central role of adrenomedullin in host defense. J Leukoc Biol 2006; 80: 237-244.

8 Wimalawansa SJ. Amylin, calcitonin gene-related peptide, calcitonin, and adrenomedullin: a peptide superfamily. Crit Rev Neurobiol 1997; 11: 167-239.

9 Wimalawansa SJ. Calcitonin gene-related peptide and its receptors: molecular genetics, physiology, pathophysiology, and therapeutic potentials. Endocr Rev 1996; 17: 533-585.

10 Joyce CD, Fiscus RR, Wang X, Dries DJ, Morris RC, Prinz RA. Calcitonin gene-related peptide levels are elevated in patients with sepsis. Surgery 1990; 108: 1097-1101.

11 Ueda S, Nishio K, Minamino N, et al. Increased plasma levels of adrenomedullin in patients with systemic inflammatory response syndrome. Am J Respir Crit Care Med 1999; 160: 132-136.

12 Muller B, Becker KL, Schachinger H, et al. Calcitonin precursors are reliable markers of sepsis in a medical intensive care unit. Crit Care Med 2000; 28: 977-983.

13 Muller B, White JC, Nylen ES, Snider RH, Becker KL, Habener JF. Ubiquitous epression of the calcitonin-I gene in multiple tissues in response to sepsis. J Clin Endocrinol Metab 2001; 86: 396-404.

14 Snider RH Jr, Nylen ES, Becker KL. Procalcitonin and its component peptides in systemic inflammation: immunochemical characterization. J Investig Med 1997; 45: 552-560.

15 Weglohner W, Struck J, Fischer-Schulz C, et al. Isolation and characterization of serum procalcitonin from patients with sepsis. Peptides 2001; 22: 2099-2103.

16 Becker KL, Müller B, Nylen ES, Cohen R, Silvia OL, Snider RH. Calcitonin gene family of peptides. In: Becker KL, ed. Principles and Practice of Endocrinology and Metabolism. Philadelphia, JB Lippincott Co., 2001; pp. 520-531.

17 Preas HL 2nd, Nylen ES, Snider RH, et al. Effects of antiinflammatory agents on serum levels of calcitonin 
precursors during human experimental endotoxemia. J Infect Dis 2001; 184: 373-376.

18 Nijsten MW, Olinga P, Hoekstra HJ. In vitro and in vivo stimulation of procalcitonin by $\mathrm{TNF} \alpha$ and IL-6. J Anästhesie Intensivtherapie 2001; 2: 58-60.

19 Silva O, Wisneski LA, Cyrus J, Snider RH, Moore CF, Becker KL. Calcitonin in thyroidectomized patients. Am J Med Sci 1978; 275: 159-164.

20 Martinez JM, Wagner KE, Snider RH, et al. Late immunoneutralization of procalcitonin arrests the progression of lethal porcine sepsis. Surg Infect (Larchmt) 2001; 2: 193-202; discussion 202-203.

21 Wagner KE, Martinez JM, Vath SD, et al. Early immunoneutralization of calcitonin precursors attenuates the adverse physiologic response to sepsis in pigs. Crit Care Med 2002; 30: 2313-2321.

22 Morgenthaler NG, Struck J, Chancerelle Y, et al. Production of procalcitonin (PCT) in non-thyroidal tissue after LPS injection. Horm Metab Res 2003; 35: 290-295.

23 Nijsten MW, Olinga $\mathrm{P}$, The $\mathrm{TH}$, et al. Procalcitonin behaves as a fast responding acute phase protein in vivo and in vitro. Crit Care Med 2000; 28: 458-461.

24 Suarez Domenech V, White JC, Nylen ES, et al. Calcitonin gene-related peptide expression in sepsis: postulation of microbial infection-specific response elements within the calcitonin I gene promotor. I Investig Med 2001; 49: 514-521.

25 Simon L, Gauvin F, Amre DK, Saint-Louis P, Lacroix J. Serum procalcitonin and C-reactive protein levels as markers of bacterial infection: a systematic review and meta-analysis. Clin Infect Dis 2004; 39: 206-217.

26 Christ-Crain M, Muller B. Procalcitonin in bacterial infections - hype, hope, more or less? Swiss Med Wkly 2005; 135: 451-460.

27 Linscheid P, Seboek D, Zulewski H, et al. Cytokineinduced metabolic effects in human adipocytes are independent of endogenous nitric oxide. Am J Physiol Endocrinol Metab 2006; 290: E1068-E1077.

28 Russwurm S, Reinhart K. Procalcitonin mode of action: new pieces in a complex puzzle. Crit Care Med 2004; 32: 1801-1802.

29 Canale DD, Donabedian RK. Hypercalcitoninemia in acute pancreatitis. J Clin Endocrinol Metab 1975; 40: 738-741.

30 Mallet E, Lanse X, Devaux AM, Ensel P, Basuyau JP, Brunelle P. Hypercalcitoninaemia in fulminant meningococcaemia in children. Lancet 1983; 1: 294.

31 Chesney RW, McCarron DM, Haddad JG, et al. Pathogenic mechanisms of the hypocalcemia of the staphylococcal toxic-shock syndrome. J Lab Clin Med 1983; 101: 576-585.

32 Becker K, Silva O, Snider R, et al., The pathophysiology of pulmonary calcitonin. In: Becker K, Gazdar A, eds. The Endocrine Lung in Health and Disease. Philadelphia, WB Saunders Co., 1984; pp. 277-279.

33 Becker KL, Snider RH, Silva OL, Moore CF. Calcitonin heterogeneity in lung cancer and medullary thyroid cancer. Acta Endocrinol (Copenh) 1978; 89: 89-99.

34 Bihan H, Becker KL, Snider RH, et al. Calcitonin precursor levels in human medullary thyroid carcinoma. Thyroid 2003; 13: 819-822.
35 Snider RH, Silva OL, Becker KL, Moore CF. Letter: Heterogeneity of calcitonin. Lancet 1975; 1: 49-50.

36 Le Moullec JM, Jullienne A, Chenais J, et al. The complete sequence of human preprocalcitonin. FEBS Lett 1984; 167: 93-97.

37 Assicot M, Gendrel D, Carsin H, Raymond J, Guilbaud J, Bohuon C. High serum procalcitonin concentrations in patients with sepsis and infection. Lancet 1993; 341: 515-518.

38 Gendrel D, Assicot M, Raymond J, et al. Procalcitonin as a marker for the early diagnosis of neonatal infection. J Pediatr 1996; 128: 570-573.

39 de Werra I, Jaccard C, Corradin SB, et al. Cytokines, nitrite/nitrate, soluble tumor necrosis factor receptors, and procalcitonin concentrations: comparisons in patients with septic shock, cardiogenic shock, and bacterial pneumonia. Crit Care Med 1997; 25: 607-613.

40 Gerard Y, Hober D, Assicot M, et al. Procalcitonin as a marker of bacterial sepsis in patients infected with HIV-1. J Infect 1997; 35: 41-46.

41 Meisner M. Pathobiochemistry and clinical use of procalcitonin. Clin Chim Acta 2002; 323: 17-29.

42 Whang KT, Steinwald PM, White JC, et al. Serum calcitonin precursors in sepsis and systemic inflammation. J Clin Endocrinol Metab 1998; 83: 3296-3301.

43 Meisner M, Brunkhorst FM, Reith HB, Schmidt J, Lestin HG, Reinhart K. Clinical experiences with a new semi-quantitative solid phase immunoassay for rapid measurement of procalcitonin. Clin Chem Lab Med 2000; 38: 989-995.

44 Levy MM, Fink MP, Marshall JC, et al. 2001 SCCM/ ESICM/ACCP/ATS/SIS International Sepsis Definitions Conference. Intensive Care Med 2003; 29: 530-538.

45 Muller B, Becker KL, Kranzlin M, et al. Disordered calcium homeostasis of sepsis: association with calcitonin precursors. Eur J Clin Invest 2000; 30: 823-831.

46 Muller B, Peri G, Doni A, et al. High circulating levels of the IL-1 type II decoy receptor in critically ill patients with sepsis: association of high decoy receptor levels with glucocorticoid administration. J Leukoc Biol 2002; 72: 643-649.

47 Galetto-Lacour A, Zamora SA, Gervaix A. Bedside procalcitonin and C-reactive protein tests in children with fever without localizing signs of infection seen in a referral center. Pediatrics 2003; 112: 1054-1060.

48 Uzzan B, Cohen R, Nicolas P, Cucherat M, Perret GY. Procalcitonin as a diagnostic test for sepsis in critically ill adults and after surgery or trauma: a systematic review and meta-analysis. Crit Care Med 2006; 34: 1996-2003.

49 Marc E, Menager C, Moulin F, et al. [Procalcitonin and viral meningitis: reduction of unnecessary antibiotics by measurement during an outbreak]. Arch Pediatr 2002; 9: 358-364.

50 Muller B, Harbarth S, Stolz D, et al. Diagnostic and prognostic accuracy of clinical and laboratory parameters in community-acquired pneumonia. BMC Infect Dis 2007; 7: 10 .

51 Muller B, Prat C. Markers of acute inflammation in assessing and managing lower respiratory tract infections: focus on procalcitonin. Clin Microbiol Infect 2006; 12: Suppl. 9, 8-16. 
52 Wenzel RP, Wong MT. Managing antibiotic use impact of infection control. Clin Infect Dis 1999; 28: 1126-1127.

53 Chen DK, McGeer A, de Azavedo JC, Low DE. Decreased susceptibility of Streptococcus pneumoniae to fluoroquinolones in Canada. Canadian Bacterial Surveillance Network. N Engl J Med 1999; 341: 233-239.

54 Gonzales R, Steiner JF, Lum A, Barrett PH Jr. Decreasing antibiotic use in ambulatory practice: impact of a multidimensional intervention on the treatment of uncomplicated acute bronchitis in adults. JAMA 1999; 281: 1512-1519.

55 Guillemot D, Courvalin P. Better control of antibiotic resistance. Clin Infect Dis 2001; 33: 542-547.

56 Halm EA, Teirstein AS. Clinical practice. Management of community-acquired pneumonia. N Engl J Med 2002; 347: 2039-2045.

57 Gonzales R, Sande MA. Uncomplicated acute bronchitis. Ann Intern Med 2000; 133: 981-991.

58 Nylen ES, Muller B, Becker KL, Snyder RH. The future diagnostic role of procalcitonin levels: the need for improved sensitivity. Clin Infect Dis 2003; 36: 823-824.

59 Nylen ES, Snider RH Jr, Thompson KA, Rohatgi P, Becker KL. Pneumonitis-associated hyperprocalcitoninemia. Am J Med Sci 1996; 312: 12-18.

60 Christ-Crain M, Jaccard-Stolz D, Bingisser R, et al. Effect of procalcitonin-guided treatment on antibiotic use and outcome in lower respiratory tract infections: clusterrandomised, single-blinded intervention trial. Lancet 2004; 363: 600-607.

61 Christ-Crain M, Stolz D, Bingisser R, et al. Procalcitonin guidance of antibiotic therapy in community-acquired pneumonia: a randomized trial. Am J Respir Crit Care Med 2006; 174: 84-93.

62 Stolz D, Christ-Crain M, Bingisser R, et al. Antibiotic treatment of exacerbations of COPD: a randomized, controlled trial comparing procalcitonin-guidance with standard therapy. Chest 2007; 131: 9-19.

63 Briel M, Christ-Crain M, Young J, et al. Procalcitoninguided antibiotic use versus a standard approach for acute respiratory tract infections in primary care: study protocol for a randomised controlled trial and baseline characteristics of participating general practitioners [ISRCTN73182671]. BMC Fam Pract 2005; 6: 34.

64 Christ-Crain M, Morgenthaler NG, Stolz D, et al. Proadrenomedullin to predict severity and outcome in community-acquired pneumonia [ISRCTN04176397]. Crit Care 2006; 10: R96-R103.

65 Meehan TP, Fine MJ, Krumholz HM, et al. Quality of care, process, and outcomes in elderly patients with pneumonia. JAMA 1997; 278: 2080-2084.

66 Genne D, Kaiser L, Kinge TN, Lew D. Communityacquired pneumonia: causes of treatment failure in patients enrolled in clinical trials. Clin Microbiol Infect 2003; 9: 949-954.

67 O'Donnell WJ, Kradin RL, Evins AE, Wittram C. Case records of the Massachusetts General Hospital. Weekly clinicopathological exercises. Case 39-2004. A 52-year-old woman with recurrent episodes of atypical pneumonia. N Engl J Med 2004; 351: 2741-2749.
68 File TM Jr, Mandell LA. What is optimal antimicrobial therapy for bacteremic pneumococcal pneumonia? Clin Infect Dis 2003; 36: 396-398.

69 Mandell LA, Bartlett JG, Dowell SF, File TM Jr, Musher DM, Whitney C. Update of practice guidelines for the management of community-acquired pneumonia in immunocompetent adults. Clin Infect Dis 2003; 37: 1405-1433.

70 File TM Jr. Clinical efficacy of newer agents in shortduration therapy for community-acquired pneumonia. Clin Infect Dis 2004; 39: Suppl. 3, S159-S164.

71 Niederman MS, Mandell LA, Anzueto A, et al. Guidelines for the management of adults with community-acquired pneumonia. Diagnosis, assessment of severity, antimicrobial therapy, and prevention. Am J Respir Crit Care Med 2001; 163: 1730-1754.

72 Menendez R, Torres A, Zalacain R, et al. Guidelines for the treatment of community-acquired pneumonia: predictors of adherence and outcome. Am J Respir Crit Care Med 2005; 172: 757-762.

73 Wipf JE, Lipsky BA, Hirschmann JV, et al. Diagnosing pneumonia by physical examination: relevant or relic? Arch Intern Med 1999; 159: 1082-1087.

74 Hug B, Rossi M. A year's review of bacterial pneumonia at the central hospital of Lucerne, Switzerland. Swiss Med Wkly 2001; 131: 687-692.

75 Carratala J, Fernandez-Sabe N, Ortega L, et al. Outpatient care compared with hospitalization for communityacquired pneumonia: a randomized trial in low-risk patients. Ann Intern Med 2005; 142: 165-172.

76 Yealy DM, Auble TE, Stone RA, et al. Effect of increasing the intensity of implementing pneumonia guidelines: a randomized, controlled trial. Ann Intern Med 2005; 143: 881-894.

77 Musher DM, Alexandraki I, Graviss EA, et al. Bacteremic and nonbacteremic pneumococcal pneumonia. A prospective study. Medicine (Baltimore) 2000; 79: 210-221.

78 Tan MJ, Tan JS, Hamor RH, File TM Jr, Breiman RF. The radiologic manifestations of Legionnaire's disease. The Ohio Community-Based Pneumonia Incidence Study Group. Chest 2000; 117: 398-403.

79 Arancibia F, Bauer TT, Ewig S, et al. Communityacquired pneumonia due to gram-negative bacteria and Pseudomonas aeruginosa: incidence, risk, and prognosis. Arch Intern Med 2002; 162: 1849-1858.

80 Dixon RE. Economic costs of respiratory tract infections in the United States. Am J Med 1985; 78: 45-51.

81 May DS, Kelly JJ, Mendlein JM, Garbe PL. Surveillance of major causes of hospitalization among the elderly, 1988. MMWR CDC Surveill Summ 1991; 40: 7-21.

82 Coley CM, Li YH, Medsger AR, et al. Preferences for home versus hospital care among low-risk patients with community-acquired pneumonia. Arch Intern Med 1996; 156: 1565-1571.

83 Poses RM, Cebul RD, Wigton RS. You can lead a horse to water - improving physicians' knowledge of probabilities may not affect their decisions. Med Decis Making 1995; 15: 65-75.

84 Guest JF, Morris A. Community-acquired pneumonia: the annual cost to the National Health Service in the UK. Eur Respir J 1997; 10: 1530-1534. 
85 Seppa Y, Bloigu A, Honkanen PO, Miettinen L, Syrjala H. Severity assessment of lower respiratory tract infection in elderly patients in primary care. Arch Intern Med 2001; 161: 2709-2713.

86 Current Controlled Trials. Procalcitonin-guided antibiotic therapy and hospitalisation in patients with lower respiratory tract infections: the ProHOSP study. www.controlled-trials.com/ISRCTN95122877. Date last updated: August 2006.

87 Chastre J, Fagon JY. Ventilator-associated pneumonia. Am J Respir Crit Care Med 2002; 165: 867-903.

88 Duflo F, Debon R, Monneret G, Bienvenu J, Chassard D, Allaouchiche B. Alveolar and serum procalcitonin: diagnostic and prognostic value in ventilator-associated pneumonia. Anesthesiology 2002; 96: 74-79.

89 Oppert M, Reinicke A, Muller C, Barckow D, Frei U, Eckardt KU. Elevations in procalcitonin but not Creactive protein are associated with pneumonia after cardiopulmonary resuscitation. Resuscitation 2002; 53: 167-170.

90 Luyt CE, Guerin V, Combes A, et al. Procalcitonin kinetics as a prognostic marker of ventilator-associated pneumonia. Am J Respir Crit Care Med 2005; 171: 48-53.

91 Gibot S, Cravoisy A. Soluble form of the triggering receptor expressed on myeloid cells- 1 as a marker of microbial infection. Clin Med Res 2004; 2: 181-187.

92 Gibot S, Cravoisy A, Levy B, Bene MC, Faure G, Bollaert PE. Soluble triggering receptor expressed on myeloid cells and the diagnosis of pneumonia. $N$ Engl $J$ Med 2004; 350: 451-458.

93 Gibot S, Kolopp-Sarda MN, Bene MC, et al. Plasma level of a triggering receptor expressed on myeloid cells-1: its diagnostic accuracy in patients with suspected sepsis. Ann Intern Med 2004; 141: 9-15.

94 Mueller B, Gencay MM, Gibot S, et al. Circulating levels of soluble triggering receptor expressed on myeloid cells (sTREM-1) in community-acquired pneumonia. Crit Care Med 2007; 35: 990-991.

95 Buyse S, Lopez E, Guérin S, et al., Expression de TREM-1 soluble plasmatique au cours du SIRS. In: Proceedings of the Annual Meeting of the Société de Réanimation de Langue Française (SRLF) 2006. Paris, 2006; p. SP238.

96 Muller B. Procalcitonin and ventilator-associated pneumonia: yet another breath of fresh air. Am J Respir Crit Care Med 2005; 171: 2-3.

97 Fine MJ, Auble TE, Yealy DM, et al. A prediction rule to identify low-risk patients with community-acquired pneumonia. N Engl J Med 1997; 336: 243-250.

98 Harbarth S, Holeckova K, Froidevaux C, et al. Diagnostic value of procalcitonin, interleukin-6, and interleukin- 8 in critically ill patients admitted with suspected sepsis. Am J Respir Crit Care Med 2001; 164: 396-402.

99 Jensen JU, Heslet L, Jensen TH, Espersen K, Steffensen P, Tvede M. Procalcitonin increase in early identification of critically ill patients at high risk of mortality. Crit Care Med 2006; 34: 2596-2602.

100 Masia M, Gutierrez F, Shum C, et al. Usefulness of procalcitonin levels in community-acquired pneumonia according to the Patients Outcome Research Team pneumonia severity index. Chest 2005; 128: 2223-2229.
101 Muller B, Suess E, Schuetz P, et al. Circulating levels of pro-atrial natriuretic peptide in lower respiratory tract infections. J Intern Med 2006; 260: 568-576.

102 Christ-Crain M, Morgenthaler NG, Struck J, Harbarth S, Bergmann A, Muller B. Mid-regional pro-adrenomedullin as a prognostic marker in sepsis: an observational study. Crit Care 2005; 9: R816-R824.

103 Hinson JP, Kapas S, Smith DM. Adrenomedullin, a multifunctional regulatory peptide. Endocr Rev 2000; 21: 138-167.

104 Eto T. A review of the biological properties and clinical implications of adrenomedullin and proadrenomedullin $\mathrm{N}$-terminal 20 peptide (PAMP), hypotensive and vasodilating peptides. Peptides 2001; 22: 1693-1711.

105 Kitamura K, Kangawa K, Kawamoto M, et al. Adrenomedullin: a novel hypotensive peptide isolated from human pheochromocytoma. Biochem Biophys Res Commun 1993; 192: 553-560.

106 Hirata Y, Mitaka C, Sato K, et al. Increased circulating adrenomedullin, a novel vasodilatory peptide, in sepsis. J Clin Endocrinol Metab 1996; 81: 1449-1453.

107 Struck J, Tao C, Morgenthaler NG, Bergmann A. Identification of an adrenomedullin precursor fragment in plasma of sepsis patients. Peptides 2004; 25: 1369-1372.

108 Morgenthaler NG, Struck J, Christ-Crain M, Bergmann A, Muller B. Pro-atrial natriuretic peptide is a prognostic marker in sepsis, similar to the APACHE II score: an observational study. Crit Care 2005; 9: R37-R45.

109 Morgenthaler NG, Struck J, Thomas B, Bergmann A. Immunoluminometric assay for the midregion of proatrial natriuretic peptide in human plasma. Clin Chem 2004; 50: 234-236.

110 Aiura K, Ueda M, Endo M, Kitajima M. Circulating concentrations and physiologic role of atrial natriuretic peptide during endotoxic shock in the rat. Crit Care Med 1995; 23: 1898-1906.

111 McDonagh TA, Robb SD, Murdoch DR, et al. Biochemical detection of left-ventricular systolic dysfunction. Lancet 1998; 351: 9-13.

112 Ruskoaho H. Cardiac hormones as diagnostic tools in heart failure. Endocr Rev 2003; 24: 341-356.

113 Cowie MR, Struthers AD, Wood DA, et al. Value of natriuretic peptides in assessment of patients with possible new heart failure in primary care. Lancet 1997; 350: 1349-1353.

114 Mueller C, Laule-Kilian K, Scholer A, Perruchoud AP. Btype natriuretic peptide for risk stratification in community-acquired pneumonia. J Intern Med 2005; 258: 391-393.

115 Morgenthaler NG, Müller B, Struck J, Bergmann A, Redl $\mathrm{H}$, Christ-Crain M. Copeptin, a stable peptide of the arginine vasopressin (AVP) precursor, is elevated in hemorrhagic and septic shock. Shock 2007; [Epub ahead of print PMID: 17515850].

116 Müller B, Morgenthaler NG, Stolz D, et al. Circulating levels of copeptin, a novel biomarker, in lower respiratory tract infections. Eur J Clin Invest 2007; 37: 145-152.

117 Stolz D, Christ-Crain M, Morgenthaler NG, et al. Copeptin, C-reactive protein and procalcitonin as prognostic biomarkers in acute exacerbation of COPD. Chest 2007; 131: 1058-1067. 
118 Almirall J, Bolibar I, Toran P, et al. Contribution of Creactive protein to the diagnosis and assessment of severity of community-acquired pneumonia. Chest 2004; 125: 1335-1342.

119 Querol-Ribelles JM, Tenias JM, Grau E, et al. Plasma ddimer levels correlate with outcomes in patients with community-acquired pneumonia. Chest 2004; 126: 1087-1092.

120 Angus DC, Linde-Zwirble WT, Lidicker J, Clermont G, Carcillo J, Pinsky MR. Epidemiology of severe sepsis in the United States: analysis of incidence, outcome, and associated costs of care. Crit Care Med 2001; 29: 1303-1310.

121 Martin GS, Mannino DM, Eaton S, Moss M. The epidemiology of sepsis in the United States from 1979 through 2000. N Engl J Med 2003; 348: 1546-1554.

122 Rangel-Frausto MS, Pittet D, Hwang T, Woolson RF, Wenzel RP. The dynamics of disease progression in sepsis: Markov modeling describing the natural history and the likely impact of effective antisepsis agents. Clin Infect Dis 1998; 27: 185-190.

123 Knaus WA, Zimmerman JE, Wagner DP, Draper EA, Lawrence DE. APACHE-acute physiology and chronic health evaluation: a physiologically based classification system. Crit Care Med 1981; 9: 591-597.

124 Jochberger S, Morgenthaler NG, Mayr VD, et al. Copeptin and arginine vasopressin concentrations in critically ill patients. J Clin Endocrinol Metab 2006; 91: 4381-4386.

125 Morgenthaler NG, Struck J, Alonso C, Bergmann A. Measurement of midregional proadrenomedullin in plasma with an immunoluminometric assay. Clin Chem 2005; 51: 1823-1829.

126 Struck J, Morgenthaler NG, Bergmann A. Copeptin, a stable peptide derived from the vasopressin precursor, is elevated in serum of sepsis patients. Peptides 2005; 26: 2500-2504.

127 Whang KT, Vath SD, Becker KL, et al. Procalcitonin and proinflammatory cytokine interactions in sepsis. Shock 2000; 14: 73-78.

128 Muller B, Becker K, Snider R, et al. Procalcitonin induces the synthesis of inflammatory cytokines by human peripheral blood mononuclear cells. Abstr Intersci Conf Antimicrob Agents Chemother Intersci Conf Antimicrob Agents Chemother 1999; 39: 382.

129 Hoffmann G, Totzke G, Seibel M, Smolny M, Wiedermann FJ, Schobersberger W. In vitro modulation of inducible nitric oxide synthase gene expression and nitric oxide synthesis by procalcitonin. Crit Care Med 2001; 29: 112-116.

130 Linscheid P, Keller U, Blau N, Schaer DJ, Muller B. Diminished production of nitric oxide synthase cofactor tetrahydrobiopterin by rosiglitazone in adipocytes. Biochem Pharmacol 2003; 65: 593-598.

131 Becker KL, Bivins LE, Radfar RH, Snider RH, Moore CF, Silva OL. Study of calcitonin heterogeneity using a radioreceptor assay. Horm Metab Res 1978; 10: 457-458.

132 Suarez Domenech V, White JC, Wagner KE, et al., Nonneuroendocrine expression of the calcitonin gene family of peptides: pathophysiological role of hormokines in human sepsis. In: Proceedings of the 83rd Annual Meeting of the Endocrine Society. Denver, CO, 2001; pp. P3-P437.
133 Beer S, Weighardt H, Emmanuilidis K, et al. Systemic neuropeptide levels as predictive indicators for lethal outcome in patients with postoperative sepsis. Crit Care Med 2002; 30: 1794-1798.

134 Nishio K, Akai Y, Murao Y, et al. Increased plasma concentrations of adrenomedullin correlate with relaxation of vascular tone in patients with septic shock. Crit Care Med 1997; 25: 953-957.

135 Wang X, Wu Z, Tang Y, Fiscus RR, Han C. Rapid nitric oxide- and prostaglandin-dependent release of calcitonin gene-related peptide (CGRP) triggered by endotoxin in rat mesenteric arterial bed. Br J Pharmacol 1996; 118: 2164-2170.

136 Hayakawa H, Hirata Y, Kakoki M, et al. Role of nitric oxide-cGMP pathway in adrenomedullin-induced vasodilation in the rat. Hypertension 1999; 33: 689-693.

137 Arnalich F, Hernanz A, Jimenez M, et al. Relationship between circulating levels of calcitonin gene-related peptide, nitric oxide metabolites and hemodynamic changes in human septic shock. Regul Pept 1996; 65: 115-121.

138 Pleguezuelos O, Hagi-Pavli E, Crowther G, Kapas S. Adrenomedullin signals through NF- $\kappa \mathrm{B}$ in epithelial cells. FEBS Lett 2004; 577: 249-254.

139 Shimekake Y, Nagata K, Ohta S, et al. Adrenomedullin stimulates two signal transduction pathways, cAMP accumulation and $\mathrm{Ca}^{2+}$ mobilization, in bovine aortic endothelial cells. J Biol Chem 1995; 270: 4412-4417.

140 Pio R, Martinez A, Unsworth EJ, et al. Complement factor $\mathrm{H}$ is a serum-binding protein for adrenomedullin, and the resulting complex modulates the bioactivities of both partners. J Biol Chem 2001; 276: 12292-12300.

141 Marutsuka K, Nawa Y, Asada Y, et al. Adrenomedullin and proadrenomudullin N-terminal 20 peptide (PAMP) are present in human colonic epithelia and exert an antimicrobial effect. Exp Physiol 2001; 86: 543-545.

142 Zaks-Zilberman M, Salkowski CA, Elsasser T, Cuttitta F, Vogel SN. Induction of adrenomedullin mRNA and protein by lipopolysaccharide and paclitaxel (Taxol) in murine macrophages. Infect Immun 1998; 66: 4669-4675.

143 Marutsuka K, Hatakeyama K, Sato Y, Yamashita A, Sumiyoshi A, Asada Y. Immunohistological localization and possible functions of adrenomedullin. Hypertens Res 2003; 26: Suppl., S33-S40.

144 Martinez A, Pio R, Zipfel PF, Cuttitta F. Mapping of the adrenomedullin-binding domains in human complement factor H. Hypertens Res 2003; 26: Suppl., S55-S59.

145 Martinez A, Oh HR, Unsworth EJ, et al. Matrix metalloproteinase-2 cleavage of adrenomedullin produces a vasoconstrictor out of a vasodilator. Biochem $J$ 2004; 383: 413-418.

146 McLatchie LM, Fraser NJ, Main MJ, et al. RAMPs regulate the transport and ligand specificity of the calcitoninreceptor-like receptor. Nature 1998; 393: 333-339.

147 Lopez J, Martinez A. Cell and molecular biology of the multifunctional peptide, adrenomedullin. Int Rev Cytol 2002; 221: 1-92.

148 Nylen ES, Whang KT, Snider RH Jr, Steinwald PM, White JC, Becker KL. Mortality is increased by procalcitonin and decreased by an antiserum reactive to procalcitonin in experimental sepsis. Crit Care Med 1998; 26: 1001-1006. 
149 Martinez JM, Wagner KE, Snider RH, et al. Late immunoneutralization of procalcitonin arrests the progression of lethal porcine sepsis. Surg Infect (Larchmt) 2001; 2: 193-202.
150 Muller B, Tamm M. Biomarkers in acute exacerbation of chronic obstructive pulmonary disease: among the blind, the one-eyed is king. Am J Respir Crit Care Med 2006; 174: 848-849. 